\title{
CONTRIBUIÇÃO À GEOLOGIA DO MACIÇO ALCALINO DE POÇOS DE CALDAS
}

\author{
REINHOLT ELLERT
}

\begin{abstract}
This paper presents a study of the geology of the alkaline complex of Poços de Caldas. This massif judging from its area which is in the order of 800 square kilometers, is considered to be one of the greatest complexes formed exclusively by nephelinic rocks. Of an elliptic shape, with $35 \mathrm{~km}$ in the NE$\mathrm{SW}$ direction and $30 \mathrm{~km}$ in the NW-SE direction it possesses in addition, a stock of foyaite of about 10 square kilometers.

The Paraná sedimentary basin forms its western boundary, whilst the foothills of the Serra da Mantiqueira form the eastern boundary The complex is emplaced between granite and gneisses which, in the SE quadrant and to a lesser extend in the NW quadrant were metasomatically affected, mainly along the direction of schistosity, by the process of fenitisation. In the northwestern area the fenite is of a greenish grey colour while in the southeastern area it is red in colour

The complex consists mainly of nephelinic rocks: tinguaite and foyaite, containing however, in its interior rocks which are older than the alkaline intrusion. They are sediments and volcanic rocks formed by tuffs, breccias, agglomerates and ankaratritic lavas. The sediments accompany the contact with the gneiss. Their largest outcrops are found in the western and southern portions of the complex. The basal members of the sedimentary sequence consist of sandy shales, with horizontal bedding and the top is formed by sandstone with cross lamination. They are disturbed and usually dip towards the center of the complex. Breccias, tuffs and lavas were deposited
\end{abstract}


over the sediments and form a continuous band along the N-W border The breccias are formed chiefly by fragments of sediments, gneiss, diabase and lava. The matrix is rich in detritic well rounded quartz. The action of hydrothermal solutions, during the metasomatic process, is indicated by the appearence of autigenic biotite, microcristals of aegerine and apatite. In the matrix, secondary calcite is very common and often substitutes partially of totally the quartz.

The ankaratritic lavas frequently form agglomerates. Products of the volcanic activity are found along the whole internal border, indicating that the volcanic activity covered a large area. After this activity phonolites. tinguaites and foyaites were formed, with frequent changes from one type of rock to another. The tinguaites constitue the major area of the complex and reveal great uniformity In some areas, especially in the neighbourhood of Cascata varieties of pseudoleucite and analcite appear

The foyaites are intrusive in the tinguaites, but the emplacement occured more or less contemporaneously as is suggested by the change of one type of rock into the other Besides the various types of foyaites, with equigranular and trachitoidal textures, lujaurite and chibinite appear in a small area at the northern part of the massif.

The initial stages of the intrusion seem to have been accompanied by the up-rising of blocks of the cristalline basement, which preceded the volcanic activity Either during or aiter the volcanic activity the subsidence of the central part occured, with the formation of radial and circular faults, which permited the up-rising of the magma. The existence, even at the present level of erosion, of small areas of volcanic material, disturibed by the intrusion, indicates that the subsidence was not total, but that parts of the volcanic cover served as a roof for the emplacement of the tinguaite and the differentiation of foyaite. The great annular dike of tinguaite was emplaced along the periphery, forming a nearly complete ing of varying thickness, with vertical or nearly vertical dips. The deduction of the geometrical form of the tinguaitic in- 
trusion, in the central part of the massif is made difficult by the great mineral and textural homogeneity of the rocks. The subsidence must have started in the center, where it was most pronounced and it must have preceeded the formation of the annular dike. This is proved by the observation of many xenoliths of rocks belonging to the interior of the massif occuring in the ring-dike. The last events of the magmatic action are represented by foyaitic intrusions in the form of smaller dikes cutting the great annular dike. The sequence of the different intrusions seems to be from the centre to the periphery

The topography shows two areas with different geomorphological features: the major area, with annular drainage and the smaller with a relief between youth and maturity, in which the radial drainage predominates. It is probable that the drainage system is controlled by the main system of joints.

After the activity of the alkaline magma faulting occured over a large area. The main faulting system formed the E-W "graben" which touches the southern border of the complex.

The mineral resources consist of bauxite ores, zirconiferous minerals, as zircon, "caldasite", baddeleyte which have variable content of uranium, and deposits of thorium and rare earths. The minerals with zirconium and thorium were formed by phenomena related to hydrothermal processes, which distroyed the primary minerals and caused precipitations along joints. 



\section{INTRODUÇÃO}

Aos maciços alcalinos do mundo inteiro coube nos últimos cinqüenta anos a atenção especial dos geólogos e petrógrafos para a elucidação dos processos geológicos e petrológicos que lhes deram origem.

No Brasil, onde as ocorrências/de intrusões alcalinas, no escudo cristalino, são numerosas e algumas de área considerável, poucos levantamentos geológicos foram feitos para a elucidação dos processos responsáveis por tais jazimentos.

$O$ presente trabalho apresenta uma tentativa para a compreensão da geologia do complexo alcalino de Poços de Caldas. A existência de mapas topográficos atualizados nas escalas de 1:10.000 e 1:25.000 facilitou a apresentação do mapa geológico Os trabalhos de campo foram realizados principalmente durante os meses de férias escolares dos anos de 1954 a 1957, quando contamos com a colaboração dos colegas José Moacyr V Coutinho e Alfredo J Simon Björnberg, que muito contribuiram para a apresentação dêste trabalho .

O complexo alcalino aqui estudado situa-se nos limites dos Estados de São Paulo e Minas Gerais, ocupando neste a sua maior área, que é da ordem de 800 quilômetros quadrados, colocando-se assim entre as maiores manifestações alcalinas do mundo, superada apenas pelos maciços da Península de Kola, na Rússia, com 1.300 quilômetros quadrados (Eliseęv et al. 1937) e do Itatiaia, no Brasil, com 1.200 quilômetros quadrados (Lamego, 1936), sendo comparável aos jazimentos de Pilansberg, no Transvaal, (Shand, 1929) e de Illimaussak, na Groenlàndia, (Ussing, 1911) A sua forma é ligeiramente elítica, com () eixo maior, de 35 quilômetros, no sentido NE-SW e o menor, com 30 quilometros, no sentido NW-SE, possuindo ainda um pequeno "stock" de foiaito, no bordo NE, de aproximadamente $\tilde{j}$ quilômetros de comprimento por 2,5 quilômetros de largura, 
separado do maciço por uma faixa de gnaisse de 1,5 quilômetros. A região é há muito conhecida pelas suas fontes de águas termais, medicinais e radioativas de Aguas da Prata, Poços de Calclas e Pocinhos do Rio Verde, situadas respectivamente nos setores W. $\mathrm{N}$ e E do complexo alcalino.

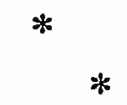

Desejo consignar os sinceros agradecimentos ao Conselho Nacional de Pesquisas pelo auxílio concedido para os trabalhos de campo, à Comissão Nacional de Energia Nuclear a impressão do Mapa Geológico, ao Prof. Dr. Elysiário Távora, da Universidade do Brasil e aos Drs. Max White e Gene Tolbert pela ajuda desinteressada. Ao Eng. Geraldo C. Melcher, da Universidade de S. Paulo, por ter fornecido parte da bibliografia especializada e ao Eng. Resk Frahya, do Departamento Nacional da Produção Mineral, pelos dados de sondagens.

Ao Prof. Dr. Viktor Leinz, Diretor do Departamento de Geologia e Paleontogia, pelo seu estímulo, orientação e crítica valiosa, a minha gratidão.

\section{TRABALHOS ANTERIORES}

O primeiro trabalho sôbre a geologia de Poços de Caldas data do século passado e foi realizado por Derby (1887) Teve c. méritc de reconhecer a natureza vulcânica da região, bem como mostrar que rochas de granulação fina, os fonólitos, podem passar a rochas de granulação grosseira como os foiaitos. Machado (1888) apresentou um excelente e minucioso estudo petrográfico das rochas da região. Trabalhos de natureza petrográfica foram realizados por Guimarães (1947, 1953) ciue advogou para o magrna alcalino uma origem por diferenciacáo do magma básico, responsável pelos derrames de basalto do Sul do Brasil. Barbosa (1934, 1936 e 1948) apresentou observações geológicas e petrográficas reivindicando para o macico duas atividades do magma alcalino, muito distanciadas no tempo, situando a primeira, de natureza plutônica, no pré-orcioviciano e a segunda, vulcânica, no fim do mesozóico. Freitas 
(1947) publicou um trabalho sôbre a geomorfologia da região. Iranco (1956) fêz um estudo sôbre a petrografia de algumas rochas, acompanhado de um mapa geológico esquemático que abrange pequena área do bordo $\mathrm{W}$ do maciço. Foram também publicados vários estudos e pesquisas sôbre os recursos minerais da região, como bauxita (Teixeira, 1937), zircão (Teixeira, 1937, Franco, 1947 e Guimarães, 1948) e ùltimamente sôbre os minerais radioativos (Tolbert, 1958, Guimarães et al., 1953)

\section{GEOLOGIA REGIONAL,}

A região de Poços de Caldas acha-se geològicamente nos limites da bacia sedimentar do Paraná e dos contrafortes da serra da Mantiqueira.

Ao redor da intrusão alcalina, com exceção do tôpo da serra do Mirante da Fartura, afloram rochas do embasamento cristalino, formadas de granito e gnaisse, com gnaissificação predominante N-40-70W Diques de diabásio, anfibolito e tinguaito cortam freqüentemente estas rochas. A xistosidade e o mergulho do gnaisse são variáveis. Assim, no bordo norte do maciço, a direção predominante é NW-SE, com mergulho para o sul. No entanto, no boŕdo $\mathrm{SW}$, a direção do gnaisse é de N-50-70E e no quadrante SE, a direção geral é NW-SE, mergu1tando para o norte e para o sul.

Nessa regiāo e em menor escala no bordo NW o gnaisse foi afetado metassomàticamente pela intrusão alcalina, sofrendo o processo de fenitização. Para o termo fenito usamos o conceito de Eckermann (1951, p. 27), como sendo rochas do contacto com a intrusão alcalina alteradas metassomàticamente "In situ" Na área SE, o fenito e gnaisse formam a serra da Pedra Branca, que se eleva a mais de 1700 metros. em forma de crescente. A passagem do gnaisse ao fenito é brusca no sentido normal à gnaissificação, enquanto que aparentemente gradual, com interdigitações ao longo da xistosidade. A côr rósea t' a orientação dos minerais no gnaissse e no fenito são concordantes, havendo neste, variação no tamanho dos minerais, enriquecimento de piroxênios, diminuição e desaparecimento do 
quartzo, que é preservado sòmente em veios e pegmatitos. Em faixas pegmatíticas a orientação dos minerais é paralela aos contactos e concordante com a orientação dos minerais do fenito. Mesmo em rochas aparentemente frescas são comuns pequenas cavidades preenchidas por material ocreoso. Entre Pocinhos do Rio Verde e Caldas o fenito forma uma escarpa abrupta e o contacto com o gnaisse é quase paralelo à estrada de rodagem que une as duas localidades, afastando-se para SE nas proximidades da cidade de Caldas.

$\mathrm{Na}$ área NW. o gnaisse de côr rósea foi transformado em fєnito, de côr cinza esverdeada, considerado por Freitas (1956) como akerito. Do gnaisse para o fenito, ao longo da estrada de rodagem Cascata - São Roque da Fartura pode ser observada a seguinte seqüência:

a - Em primeiro lugar, a mudança da côr rósea dos feldspatos no gnaisse para côr cinza esverdeada, em zonas irregulares.

b - Diminuição do teôr de quartzo na rocha.

c - Aumento do tamanho dos minerais, principalmente dos feldspatos.

d - Aparecimento de anfibólios sódicos.

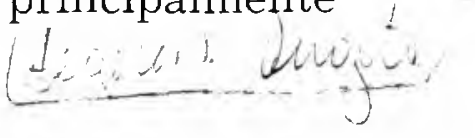

Esta seqüência assemelha-se à formação dos fenitos brancos de Spitzkop, Africa do Sul, descritos por Strauss e Truter (195̆4, p. 89) A evolução do processo da fenitização é estudada petrogràficamente e descrita por Coutinho (1959)

\section{GEOLCGIA DO MACIÇO ALCALINO \\ Sedimentos}

No bordo interno do maciço, acompanhando o contacto com as encaixantes, ocorrem sedimentos anteriores às atividades do magma alcalino e estão conservados entre rochas piroclásticas, lavas e tinguaitos. As áreas de maiores afloramentos são em Aguas da Prata e ao norte de Andradas, onde formam pacotes de mais de 100 metros de espessura. Constituem-se na base, de folhelhos com intercalações de camadas arenosas e no tópo de arenitos com estratificação cruzada. Êstes estão geral- 
mente silicificados e recristalizados, o que não se dá com os folhelhos, onde não se notam sinais de recristalização, mesmo quando cortados por diques de rochas alcalinas. Nos sedimentos ocorrem intrusões de diabásio, que aparecem em diques e pequenos sills irregulares e afloram, principalmente, ao norte de Águas da Prata e em menor escala, ao norte de Andradas, na fazenda Pinheirinho. A sua textura e composição mineral permitem analogia com as demais intrusões básicas do Mesozoico (Coutinho, 1959)

Os sedimentos foram identificados em Águas da Prata por Derby (1887), que os considerou duvidosamente carboníferos. Barbosa (1936) e Freitas (1943) compararam os folhelhos da base com os da formação Estrada Nova (Permiano) e os arenitos do tôpo, com estratificação cruzada, ao Arenito Botucatu ('Triássico), e foram petrogràficamente estudados por Björnberg (1959) Arenitos e folhelhos foram perturbados e deslocados de suas posições iniciais, principalmente nas proximidades do contacto com o tinguaíto, como ao norte de Andradas, onde se apresentam dobrados e intensamente falhados, com mergulho próximo à vertical. Quando menos perturbados, o mergulho dos sedimentos é, em geral, para dentro do maciço

\section{BRECHAS E TUFOS}

Rochas de origem vulcânica como tufos, brechas e aglomerados foram reconhecidas por Derby (1887), ao longo do vale do Quartel, entre Águas da Prata e Cascata. Ocorrem ainda em varios pontos, acompanhando o bordo interno do complexo, geralmente associadas a arenitos e lavas.

A área de maior número de afloramentos é uma faixa em forma de crescente, com largura variável, abrangendo o quadrante N-NW-W do maciço. As brechas parecem ser de duas origens:

a - vulcânica, propriamente dita.

b - brechas de origem vulcânica, com transporte posterior, assentando-se em camadas com alternância de fragmentos mais grosseiros na base e finos no tôpo. 
Nesta área, onde brechas e tufos formam uma faixa quase contínua, observa-se que foram depositados sôbre arenitos ou intercalados com lavas. No vale do Quartel, as brechas são ricas em fragmentos angulosos, cujos diâmetros, em geral, não excedem $10 \mathrm{cms}$; êles são formados, principalmente, de gnaisse, arenito, siltito e diabásio (figs. 1 e 2 ) No cimento são abundantes calcita e quartzo detrítico, geralmente arredondado, irıdicando contribuição dos sedimentos. Quando fresca, a brecha apresenta côr escura, entre castanho e roxo, provàvelmente graças à abundância de ferro no cimento areno-argiloso. Desde Cascata até as proximidades da cidade de Poços de Caldas afloram principalmente tufos e brechas com pequenas intercalações de lavas aglomeráticas alteradas. Quando fresca a brecha possui côr verde clara, com manchas azuladas, de contornos irregulares (fig. 3) Em geral, os fragmentos são escassos e são constituidos principalmente por arenito recristalizado, gnaisse e diabásio albitizado. Formam pacotes espêssos, tendo uma sondagem, na barragem Bortolan, atravessado quase 80 metros sem grande variação litológica. O cimento é rico em quartzo detrítico, calcita, feldspatos, apatita e pequenos prismas de aegerina. $O$ quartzo não raro acha-se substituido yarcial ou totalmente por calcita e os piroxênios parecem ser secundários, como produto de metassomatismo provenientes de soluções do magma alcalino. Nas proximidades do contacto com o tinguaíto a quantidade de quartzo diminui, chegando mesmo, em alguns casos, a desaparecer Quando apresentam estratificação, tufos e brechas mergulham, no geral, para o interior do maciço

No bordo E, junto com arenitos, ocorrem pequenas faixas de brechas, bem como na área $\mathrm{SE}$, nas proximidades do contacto com o fenito. A brecha apresenta estratificação, com alternância de camadas constituídas de fragmentos grosseiros e finos. Nestes afloramentos, aparentemente de pequena espessura, as brechas estão alteradas e cortadas por tinguaíto.

Ocorre ainda, no vale do Quartel, um aglomerado vulcânico, formado por fragmentos de tamanho desde alguns milímetros até mais de 10 centímetros de diâmetro, constituídos de 


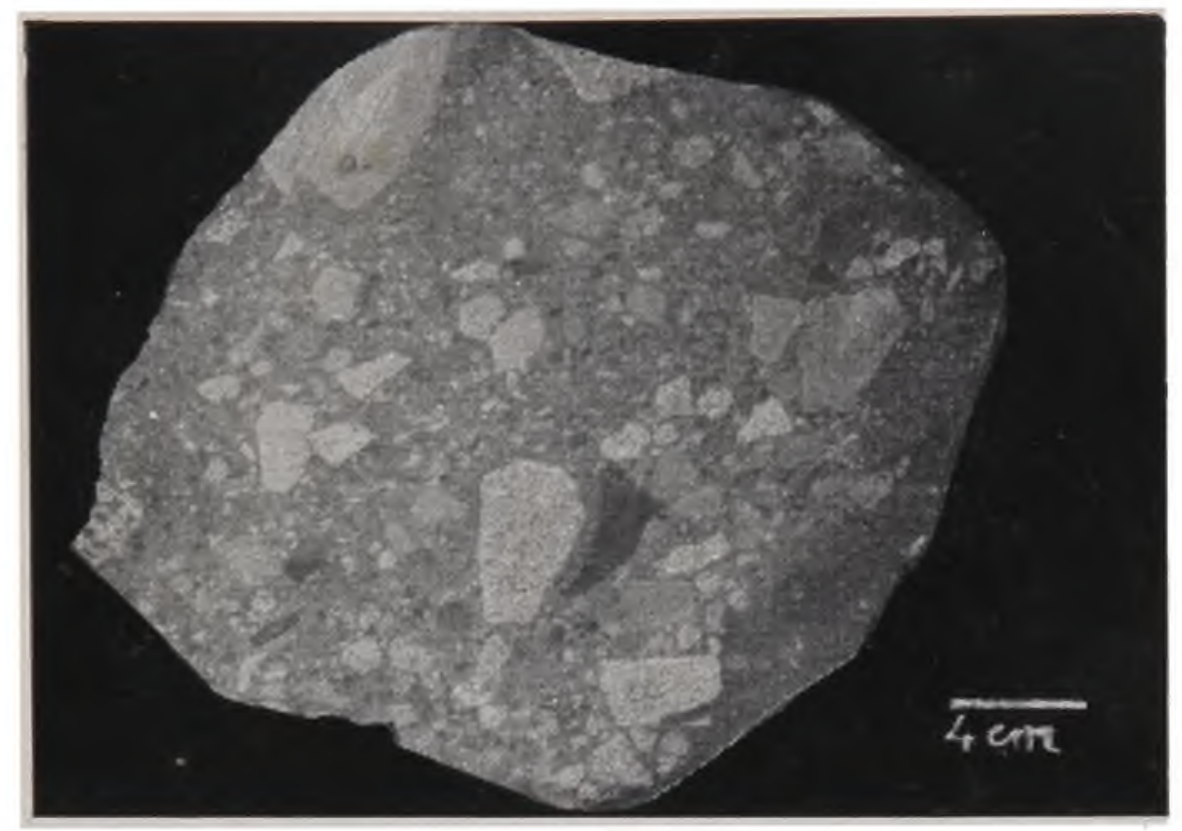

Fig. 1 - Brecha vulcânica com fragmentos angulosos de arenito e diabásio Ấguas da Prata .

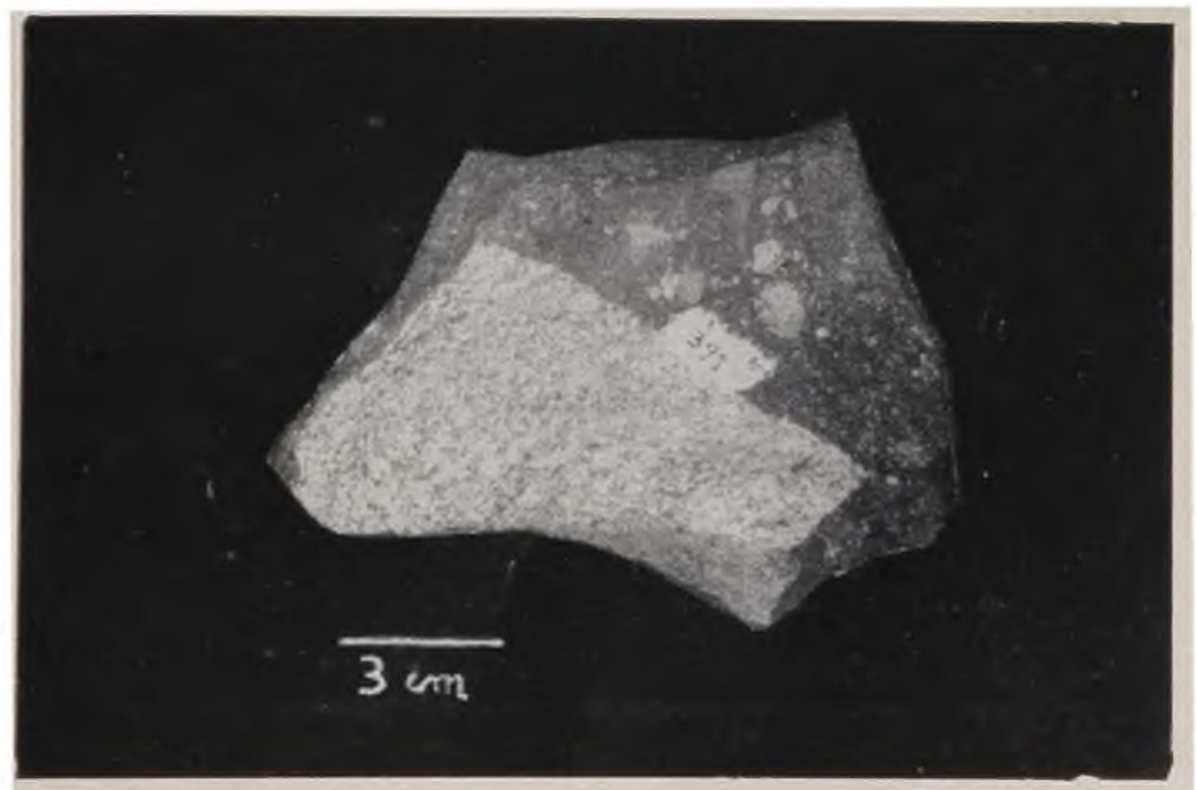

Fig. 2 - Brecha vulcânica com fragmento anguloso de diabásio. Águas da Prata. 
lavas ankaratríticas e cimentados por minerais fragmentados da lava, como augita, titanoaugita, olivina cloritizada e calcita secundária. A alteração de piroxênios e olivina êm clorita e depois para calcita é comum tanto em amostras de superfície como em testemunhos de sondagem, de mais de 70 metros de profundidade.

\section{ROCHAS EFUSIVAS E HIPABISSAIS}

\section{1 - Ankaratritos}

Rochas extrusivas, às vêzes com aspecto d̀e. lavas aglomeráticas, aparecem em extensos afloramentos no bordo NW-WSW do maciço, assentadas sôbre sedimentos ou intercaladas com tufos e brechas, com acamamentos e mergulhos variáveis, mas quase sempre com ângulos menores do que $30^{\circ}$, dirigidos para o interior do maciço. Boas exposições ocorrem no vale do Quartel entre Águas da Prata e Cascata, onde as lavas, quando frescas mostram côr cinza escura, com texturas microcristalina ou porfirítica, exibindo neste caso fenocristais de piroxênio, às vêzes com mais de $3 \mathrm{~cm}$ de comprimento. Afloramentos de lava aglomerática, na fazenda Santa Maria, exibem fragmentos com mais de $15 \mathrm{~cm}$ de diâmetro, formados de lava rica em cavidades preenchidas por calcita e cimentados por uma matriz microcristalina (fig. 4) Esta lava é cortada por diques de tinguaíto e serviu, juntamente com as brechas, de encaixante para as intrusões de tinguaíto e foiaíto. Quanto alterada é comum a decomposição esfercidal apresentando côr cinza esverdeada.

Microscòpicamente é formada por fenocristais de augita, às vêzes titanífera, sanidina, analcita e raros prismas de olivina cloritizada, dispersos em matriz microcristalina de augita, nefelina, analcita, ortoclásio, magnetita e grande quantidade de calcita secundária, pertencendo assim, à fração básica da clã alcalina. Acompanhando a faixa de brechas entre Cascata e o rio das Antas, os afloramentos de lava são raros, de pequena espessura e sempre alterados. No bordo $\mathrm{E}$ do pla- 


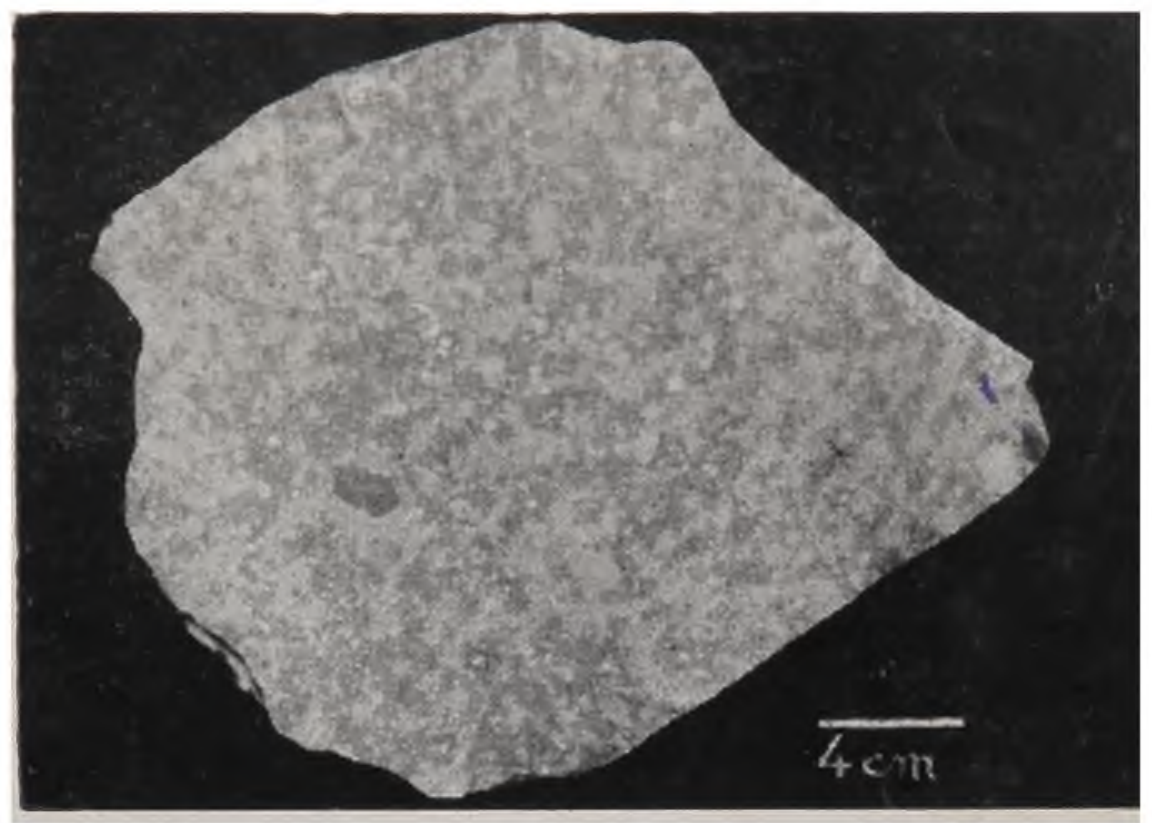

Fig. 3 - Brecha vulcânica, As zonal escuras são formadas por agregados de piroxênios aciculares. Barragem Bortolan.

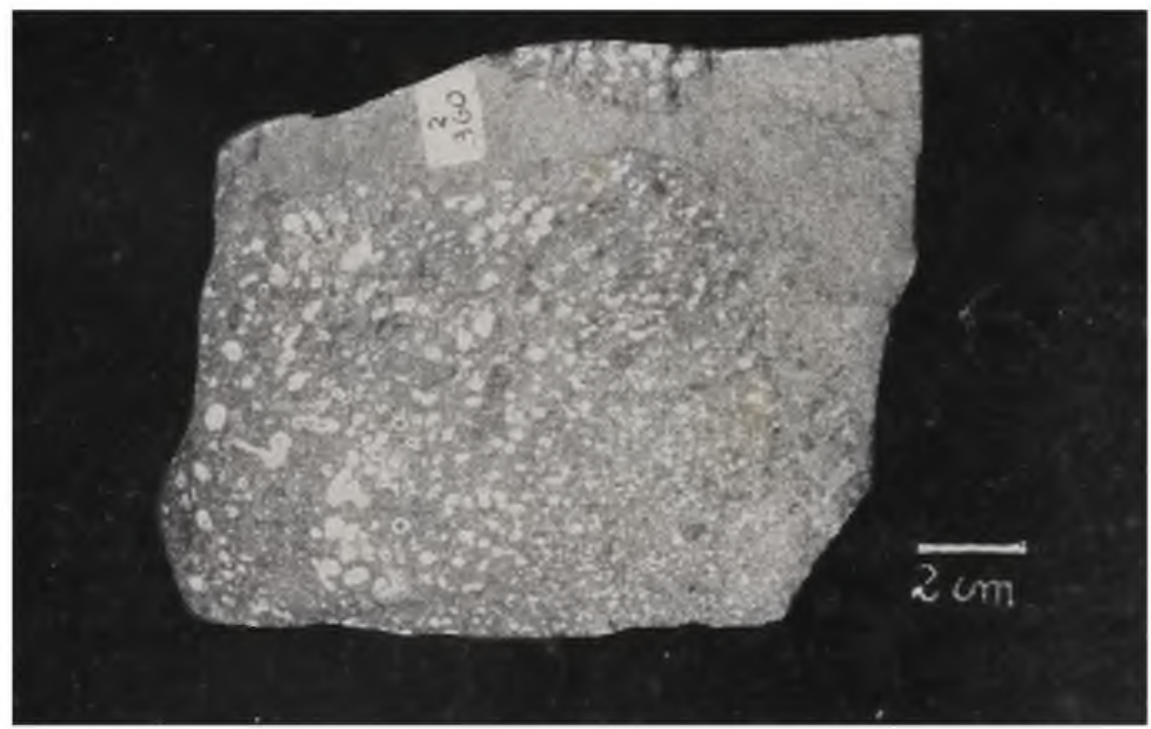

Fig. 4 - Lava ankaratritica aglomerática, rica em vesículas preenchidas por calcita. Fazenda Santa Maria. 
nalto, perto do contacto com o gnaisse, ocorre também um pequeno afloramento de lava aglomerática alterada.

\section{2 - Lavas fonolíticas}

Na área sul do planalto afloram derrames de lavas fonolíticas, com centenas de metros de espessura, capeando sedimentos, sem intercalações de tufos e brechas. Formam degraus que se ressaltam morfologicamente, com mergulho suave, para o interior do maciço, às vêzes perturbado por intrusões posteriores de tinguaito, como se pode notar nos morros do Mel e do Tamanduá. Estão quase sempre alteradas e quando frescas, sua côr é castanho escura, com textura fluidal visível, formando freqüentemente pequenas dobras irregulares, sugerindo que quando se deu o derrame a lava estava num estado semifluido. Nos derrames mais espêssos nota-se que o resfriamento mais lento permitiu a formação de textura mais grosseira assemelhando-se a tinguaíto e até mesmo a microfoiaíto. A rocha está, em geral intensamente fraturada e quando semi-alterada, a sua côr é branco amarelada, côr essa, talvez conseqüente: da percolação de soluções hidrotermais.

\section{3 - Tinguaíto e fonólito}

Quase dois têrços da área do complexo são constituídos de rochas compactas, de textura afanítica, porfirítica, sacaróide ou granular, de côres verde a quase preta e são consideradas como correspondentes efusivos e hipabissais do foiaíto. Derby (1887) considerou-as simplesmente como fonólitos, que formam derrames, diques e stoks. Segundo a classificação de Johannsen (1939, vol. 4, p. 146) usamos o têrmo fonólito para rochas de textura afanítica ou porfirítica e para as rochas de textura granular ou sacaróide o têrmo tinguaíto. No entanto, é comum a transição de um tipo a outro, o que dá a essa separação um caráter muito arbitrário, fato que também foi assinalado por Shand (1929, p. 135) No conjunto predominam as rochas consideradas como tinguaíto, que podem apresentar fases de transição para foiaito. 
No.tinguaíto, que forma o grande dique anelar, são comuns Fequenos autólitos esféricos, de poucos centímetros. de microfoiaito, onde os minerais possuem comumente disposição radial (fig. 5)

A área centro-sudeste do rnaciço é formada de tinguaíto, mas são escassos, em certas zonas os afloramentos de rochas frescas. O tinguaíto está profundamente alterado, aparecendo no campo espêssa camada de canga limonítica e laterita e no leito dos riachos a rocha semi-alterada é de côr rósea. No fundo de alguns vales, às vêzes com mais de 50 metros de profundidade, o tinguaíto apresenta côr branco-cinza, com abundantes cristais de pirita. Ao microscópio notam-se feldspatos e feldspatóides ligeiramente alterados, enquanto que dos piroxênios sòmente resta um esqueleto de material opaco. Nesta área ocorrem diques de magnetita, que se ressaltam na topografia, possuindo geralmente menos de 1 metro de espessura. São limonitizados na superfície com direção preferencial $\mathrm{NE}$ e mergulho vertical ou quase vertical, nesse caso para $\mathrm{N}$. O morro do Ferro é cortado por um dique de magnetita, com quase 3 metros de espessura, com direção NW. mergulho cêrca de $60^{\circ}$ para NE. A rocha encaixante acha-se profundamente alterada, mas segundo dados de sondagens parece ser microfoiaíto em profundidade (Branco, 1957, p. 59) Nesse morro foram descobertos importantes depósitos de tório e terras raras. São produtos secundários, formados provàvelmente por soluções hidrotermais que alteraram os minerais zirconíferos, contendo tório e terras raras, possibilitando sua concentração em forma de veios ao longo de fraturas. A ocorrência de diques de magnetita, cortando tinguaíto parcialmente alterado, poderia sugerir lixiviação do ferro dos minerais ferromagnesianos e sua posterior precipitação ao longo de fendas. No entanto, diques de magnetita, de origem magmática, associados a rochas alcalinas, são conhecidos na região das montanhas de Adirondack, ao norte de Nova Iorque (Lindgren, 1933, p. 794) Nos Urais ocorrem, em rochas sieníticas, próvàvelmente formando "schlieren" $\mathrm{e}$ também no Brasil, em Ipanema, nesse caso associados a depósitos de apatita (Leinz, 1940) 


\section{4 - Pseudo-leucita tinguaíto}

Tinguaítos com pseudomorfos de leucita são conhecidos em Poços de Caldas desde os trabalhos pioneiros de Derby (1887) e Hussak (1900) Foram originalmente considerados como derrames fonolíticos e apresentam normalmente côr cinza clara, com textura microcristalina, raras vêzes grosseira, em que os pseudomorfos têm forma aproximada de icositetraedros dispostos irregularmente e muitas vêzes concrescidos. Têm tamanho variado, desde milimétrico até mais de $20 \mathrm{~cm}$ de diâmetro. Os pseudomorfos maiores possuem, às vêzes, na parte central, um agregado de ortoclásio, nefelina, aegerina e titanita, rodeados por uma massa microcristalina de ortoclásio e nefelina. Nos limites o pseudo cristal é envolto por uma zona mais escura, milimétrica, originada pela concentração de aegerina (fig. 6) A principa, área de ocorrência é em Cascata, onde aflora em uma faixa em forma de crescente, limitada entre o analcita-tinguaito e o foiaito. Entre os morros do Serrotinho e do Serrote aparece como uma zona de poucos metros de espessura, que vai aumentando em direção a SW É anterior ao foiaíto do morro do Serrote, pois êste, no contacto é pegmatóide e emite pequenos pegmatitos para dentro do tinguaíto. No entanto, em vários pontos, principalmente nas proximidades das minas de zircão, o tinguaíto como pseudo-leucita é de textura grosseira, assemelhando-se a microfoiaíto. Contém pseudomorfos de leucita de vários tamanhos entre concentrações pegmatóides de foiaito. O contacto com o analcita-tinguaíto pode ser brusco ou transicional e nas proximidades do contacto com o foiaito passa às vêzes a tinguaíto comum. Diques de tinguaíto com pseudomorfos de leucita afloram também na serra do Quartel, cortando tinguaito. Um dos maiores, de forma ligeiramente curva, é o que aparece a NW do túnel do Pinhalzinho, na estrada de ferro, já citado por Derby (1887) Entre as estradas de ferro e de rodagem, um pouco ao norte da fazenda Santa Maria, há outro afloramento; também no tôpo da serra do Quartel, a NE do túnel do Pinhalzinho, há uma faixa de tinguaíto com pseudo-leucita. Nas proximidades da cachoeira do 


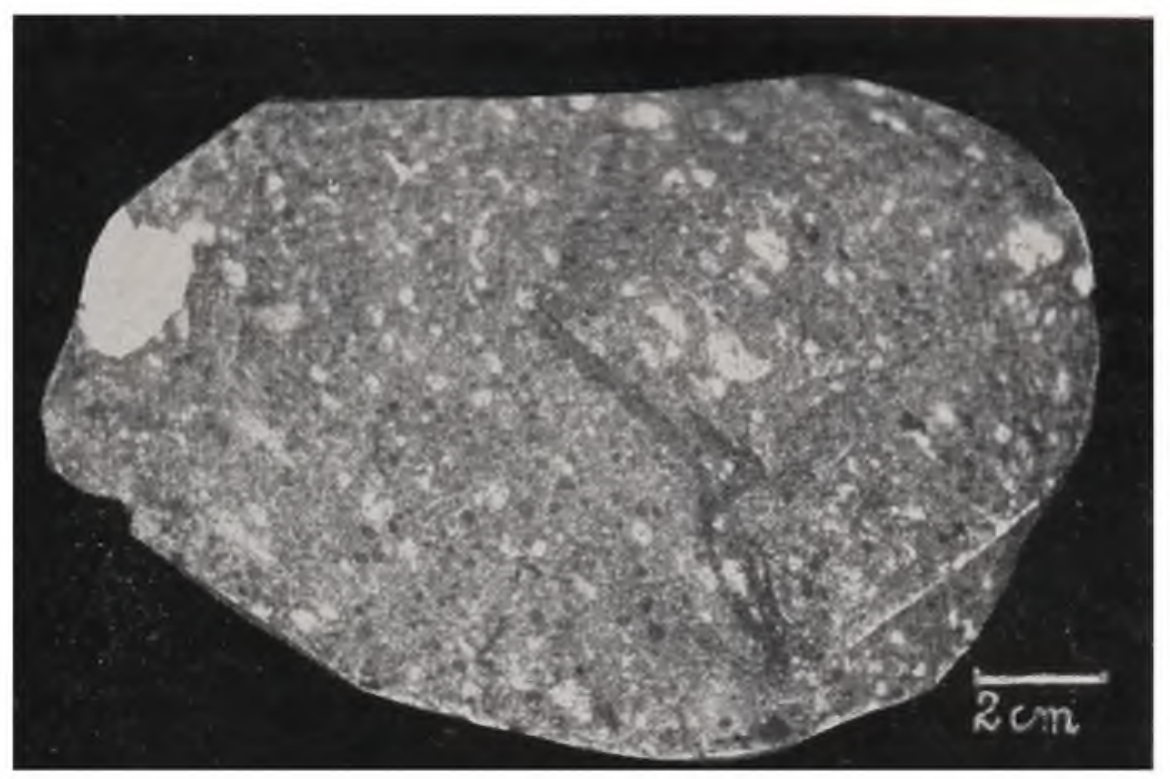

Fig. 5 - Tinguaíto do dique anelar. São abundantes pequenos autólitos de foiaito e pontos pretos formados por concentraçốes de hauina. Pedreira Bortolan.

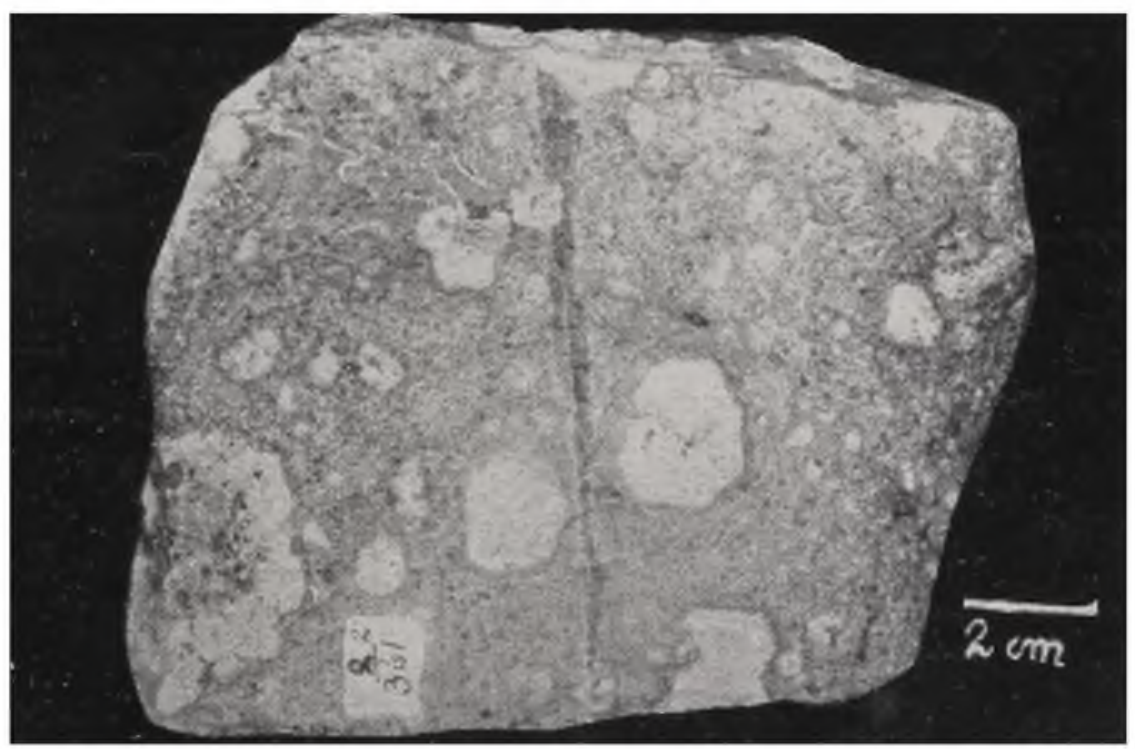

Fig. 6 - Pseudo-leucita tinguaíto. Ao redor dos pseudomorfos nota-se uma zona mais escura devida a concentração de piroxênios. Serrote. 
Ozório há um afloramento intemperizado de onde é extraído caulim rico em potássio. Outro afloramento de menor extensão aparece ao sul do morro do Taquarí, na área SE do maciço, em forma de dique irregular, encaixado ou diferenciado do tinguaito.

A singularidade do modo de ocorrência do analcita-tinguaíto e do tinguaíto com pseudo-leucita levou Shand (1929) a admitir para o jazimento de Pilansberg, a hipótese de serem os pseudomorfos, alterações a partir de analcita e não de leucita.

\section{5 - Analcita-tinguaíto ou aralcita-fonólito}

Em Cascata aflora uma faixa de fonólito porfiritico, de côr castanho escura a esverdeada, com pórfiros de analcita, do tamanho desde poucos milímetros até mais de $3 \mathrm{~cm}$, de côr rósea e contôrno mais ou menos regular de icositetraedro, dispersos numa matríz afanítica a microcristalina, com pequenas ripas de feldspato (fig. 7) Quando a rocha é de côr castanha os pórfiros de analcita são numerosos e na passagem para rocha cie côr verde escura os pórfiros diminuem em número e tamanho até desaparecerem, ressaltando-se apenas na rocha intemperizada. A maior ocorrência é uma faixa que se inicia na face $\mathrm{N}$ do morro do Serrotinho estendendo-se para SW, cobrindo uma área de vários quilômetros quadrados. Não forma com o tinguaíto contacto nítido, mas sim transicional, com o desaparecimento dos cristais de analcita. No morro do Serrotinho o analcita-tinguaíto corta a brecha vulcânica e também em pequenos afloramentos nas proximidades da fazenda Sobradinho.

Pequenos afloramentos de analcita-tinguaíto ocorrem no bordo SE do complexo, onde aparecem como diferenciações do tinguaíto.

\section{6 - Brecha de tinguaíto}

$\mathrm{Na}$ área $\mathrm{W}$ e SW do complexo, numa faixa de vários quilìmetros quadrados, ocorre uma brecha de tinguaíto. Apresenta.-se em camadas, provàvelmente de derrames, com estratifi- 


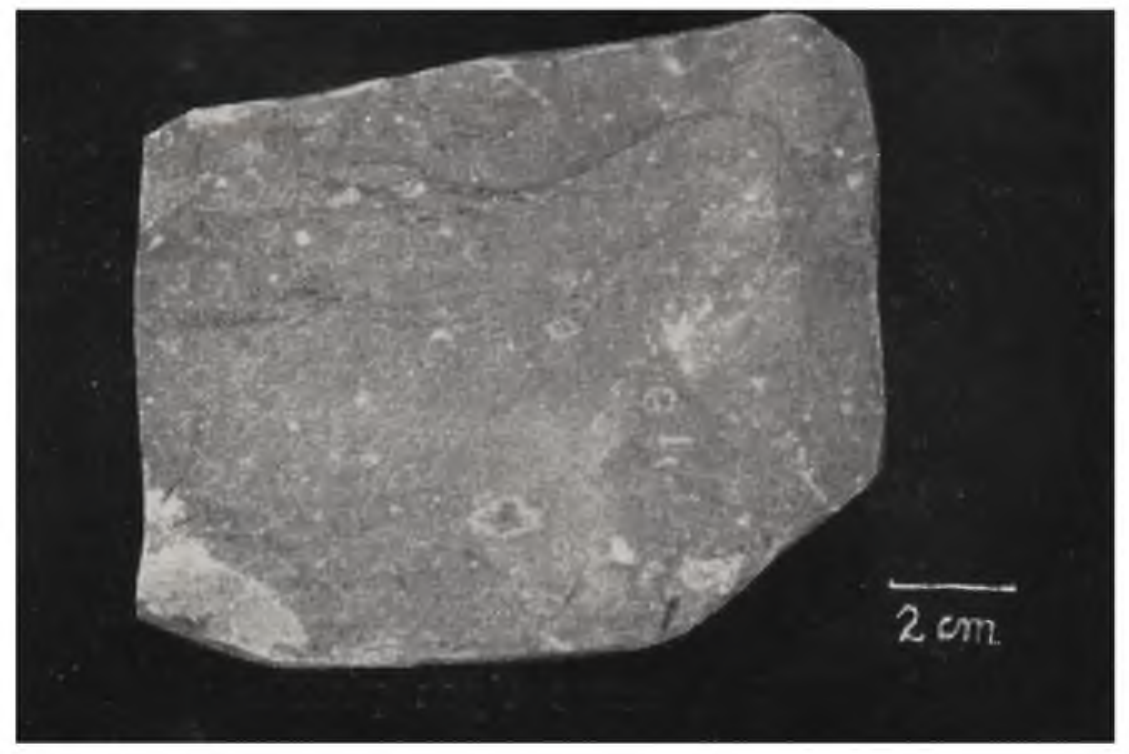

Fig. 7 - Analcita-tinguaito. Serrotinho.

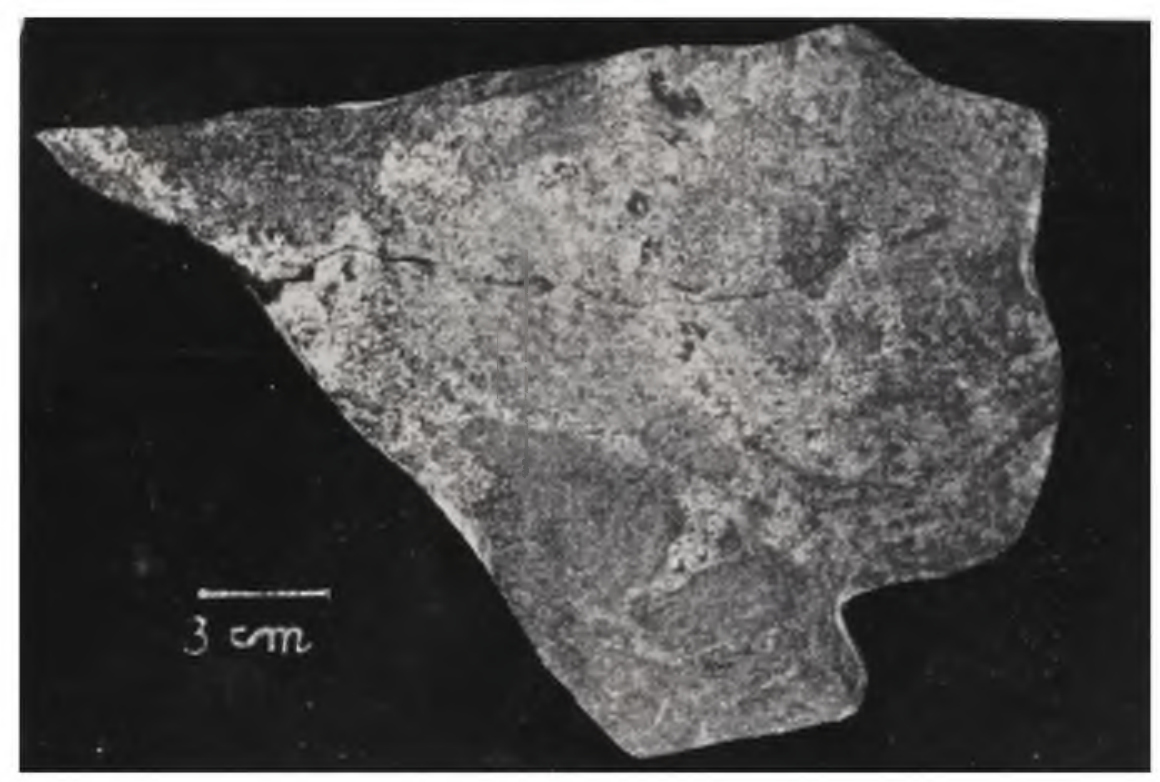

Fig. 8 - Contacto tingtaito com foiaito. O foia:to pegmató de engloba fragmentos angulosos de tinguaito. Aeroporto. 
cação variável, mas de modo geral com direção $\mathrm{NE}$ e mergulho suave para o sul. É formada de fragmentos de tinguaíto e o cimento é constituido por uma matriz fonolítica, com pórfiros de nefelina e sanidina.

\section{ROCHAS PLUTONICAS}

No maciço de Poços de Caldas apenas um têrço de sua área é constituído de rochas que podem se consideradas como representantes de atividades plutônicas. Sob êste aspecto assemelha-se ao complexo de Pilansberg (Shand, 1929), pois os demais grandes complexos alcalinos, como o da Península de Kola (Pamsay, 1894), Illimaussak (Ussing, 1911) e Itatiaia (Lamego, 1936) são formados principalmente por rochas plutônicas.

Em Poços de Caldas, como tipos plutônicos, ocorrem ar seguintes rochas:

1 - Foiaítos

2 - Foiaítos traquitóides

3 - Lujaurito e chibinito

\section{1 - Foiaítos}

Os foiaitos apresentam comumente textura granular grosseira, às vêzes ligeiramente traquitóide. Em geral são intrusivos nos tinguaítos, mas ocorrem também zonas de transição de um tipo para outro, observando-se a seqüência foiaíto-microfoiaíto-tinguaíto.

a - Foiaíto Aeroporto-Serrote - A maior área de ocorrência de foiaítos é uma faixa no sentido NE-SW na zona centro norte do maciço e aqui chamados de foiaíto "aeroporto-Serrote" O contacto do foiaíto intrusivo, ao norte do aeroporto é paralelo à textura fluidal do tinguaíto. Na faixa do contacto observa-se que quando se deu a formação do foiaíto, êste pegmatóide, englobou fragmentos de tinguaíto, de tamanho variável, que perdem seu contôrno anguloso à medida que se afastam do contacto (fig. 8) Ocorrem também fragmentos arredondados de tinguaíto, cuja textura varia de dentro para fora, passando do 
tinguaíto para uma zona de microfoiaito e depois foiaito, fazendo supor tratar-se de autólitos de tinguaito no foiaíto. Essa mesma seqüência microfoiaito-foiaíto é observada ao redor de alguns xenólitos de lavas ankaratríticas.

$\mathrm{O}$ contacto $\mathrm{NE}$ entre o foiaito e tinguaíto é aparentemente transicional o que também se dá no contacto sul desta faixa. No morro do Serrote o foiaíto aflora em forma circular e ra face norte, apesar do foiaito ser intrusivo no tinguaíto, a textura fluidal dêste é ao longo do contacto. Aí o foiaíto, de textura grosseira, não raro com bolsões pegmatóides, corta o tinguaíto em veios pegmatíticos. O foiaíto, quando pegmatóide, apresenta freqüentemente concentrações de eudialita. O paralelismo do contacto com a textura fluidal do tinguaíto permitem supor contemporaneidade da "mise-en-place" das duas rochas.

b - Foiaíto do Taquari - Nesta zona, situada na área SE do maciço, o foiaíto também é intrusivo no tinguaíto. Na faixa do cuntacto, por vários metros, apresenta-se pegmatóide, com muita fluorita, feldspatos e piroxênios formando cristais idiomorfos com mais de $5 \mathrm{~cm}$ de comprimento. A NW do morro do Taquari, no córrego do Pouso Alegre, aflora também foiaíto intrusivo no tinguaíto.

c - Foiaítos no dique anelar -- Na metade norte do maciço ocorrem faixas de foiaito, em forma de diques, cortando e acompanhando o dique anelar Apresentam contactos nítidos com o tinguaíto e freqüentemente xenólitos angulosos de tinguaíto que foram englobados com a intrusão do magma.

d - Stock Rio Pardo - Ao lado do Rio Pardo, no bordo NE do complexo, o foiaito forma um pequeno stock, com mais ou menos 10 quilômetros quadrados, que se ressalta topogràficamente do gnaisse encaixante. Êste está numa altitude média de 850-900 metros, enquanto que o tôpo do stock atinge 1.450 metros, alinhando-se no mesmo nivel que o dique anelar de tinguaíto. A forma do stock é ligeiramente alongada e corta o gnaisse diagonalmente à direção de xistosidade. Em ge- 
ral é de textura granular, uniforme, assemelhando-se ao foiaíto do aeroporto e nas proximidades do contacto, no lado E, passa em faixas irregulares a microfoiaíto. São comuns, no foiaíto, ras proximidades do gnaisse, xenólitos de até meio metro de diâmetro.

\section{2 - Foiaítos traquitóides}

a - Serras do Paiol e do Quartel - Nas serras do Paiol e do Quartel afloram foiaitos que apresentam, com o tinguaíto, contactos nítidos e também passagem gradual. Diferem um pouco dos demais foiaítos da área central do complexo pela sua textura, que é ora traquitóide, com disposição subparalela dos feldspatos tabulares, de côr branco leitosa, ora ligeiramente porfiróides, no qual os fenocristais de feldspato ressaltam-se dos minerais restantes.

b - Morro do Mel - No morro do Mel, nas proximidades do bordo S, o foiaíto corta o tinguaíto em forma de crescente. A sua textura é granular, às vêzes porfiróide ou traquitóide, com faixas em que aparecem agregados de feldspato, variando o tamanho de $1 \mathrm{~cm}$ até mais de $10 \mathrm{~cm}$, que se ressaltam pelo intemperismo. Os feldspatos, nas proximidades do tinguaíto, apresentam disposição sub-paralela acompanhando o contacto. A diferenciação das duas rochas sugere contemporaneidade, revelada pelo paralelismo da textura fluidal do tinguaito com o contacto e a passagem aparentemente gradual, no contacto $\mathrm{E}$, de uma rocha para outra.

3 - Lujaurito e Chibinito - Em forma de crescente, aflora no bordo $\mathrm{N}$ do maciço, uma faixa de lujaurito e chibinito, muito ricos em concentrações de eudialita. O lujaurito é formado de $f \in l d s p a t o s$ alongados, com disposição paralela e entre êles abundantes acículas de aegerina, com arranjo subparalelo (fig. 9)

O lujaurito passa para chibinito nas proximidades do dique anelar E' de granulação grosseira, com textura traquitóide e freqüente intercrescimento poiquilítico de feldspatos em piroxênios. Ocorrem pegmatitos irregulares, com alguns ucí- 


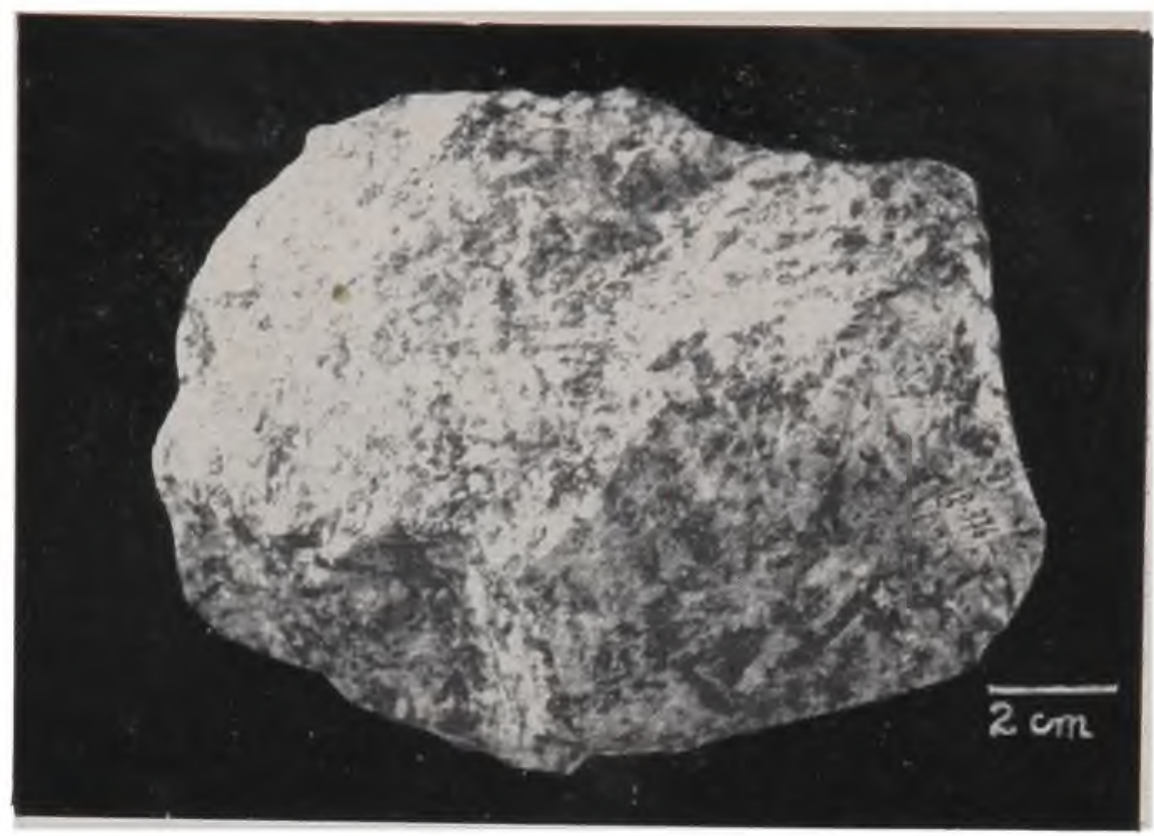

Fig. 9 - Chibinito. Proximídades Pedra Balão. Poços de Caldas.

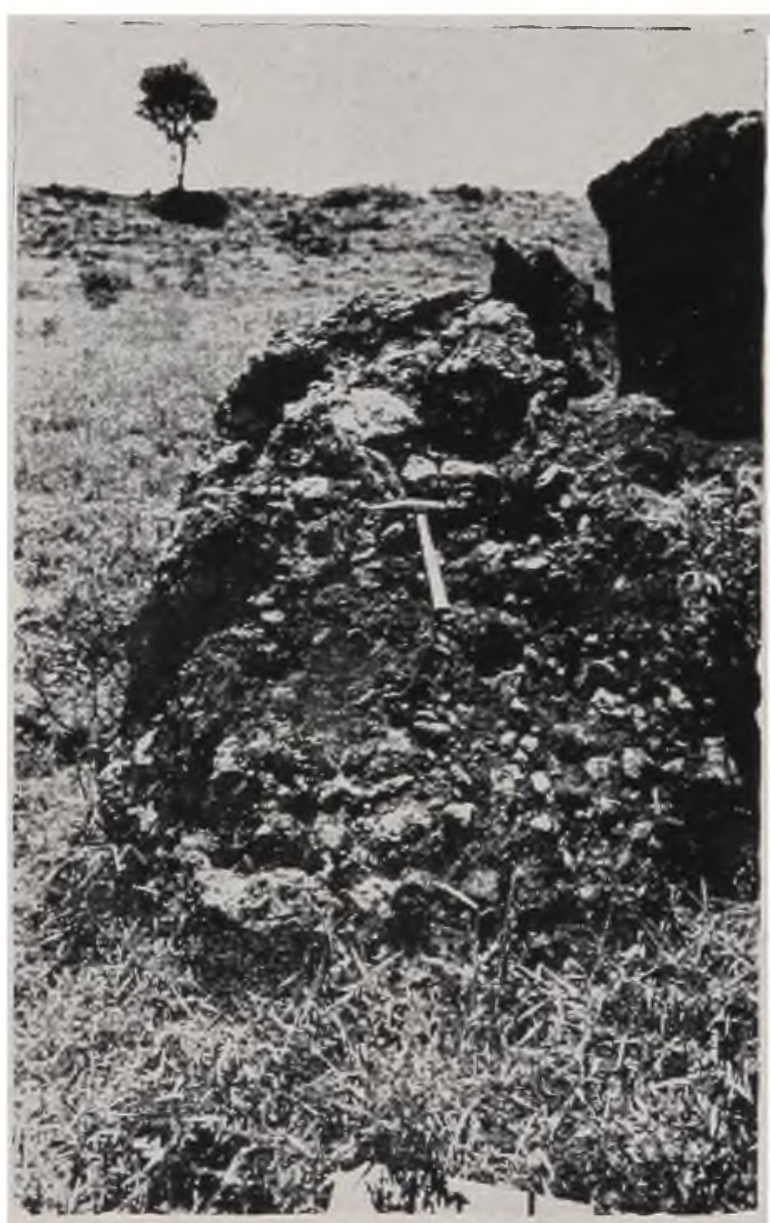

Fig, 10 - Afloramento de brecha de tinguaito. Águas da Prata. 
metros de espessura e muito ricos em eudialita. Ao longo da estrada de rodagem para Campestre notam-se massas de chibinito de granulação fina envolvidas pelo chibinito de granulação grosseira.

\section{MECANISMO DA INTRUSÃO ALCALINA}

A evolução do processo geológico de Poçrs de Caldas poderá ser assim esquematizada:

1 - Levantamentos, provàvelmente escalonados por falhas, de blocos de embasamento cristalino após a sedimentação do arenito Botucatu.

2 - Atividade vulcânica, com formação de brechas, tufos e derrames de lavas.

3 - Subsidência da parte central.

4 - Ascenção do magma nefelínico por fendas radiais e circulares e formação de fonólitos, tinguaítos e por diferenciação foiaitos.

5 - Formaçāo do dique anelar

6 - Intrusão de chibinito, lujaurito e foiaíto.

1 - Levantamentos - Os indícios de que a atividade vulcânica foi precedida ou pelo menos acompanhada de levantamentos, provàvelmente escalonados, de blocos gnaissicos, após a deposição dos sedimentos do arenito Botucatu, são indiretos e fundamentam-se tanto em observações geomorfológicas como em deduções geológicas.

a - Em Águas da Prata, no bordo W do maciço, numa altitude de 850 metros, no lado interno do complexo, ocorrem sedimentos ligeiramente perturbados, mergulhando para o interior do maciço e separados do gnaisse por uma delgada faixa de tinguaito. A NW de Aguas da Prata, a serra do Mirante da Fartura, com sedimentos assentados sôbre o gnaisse, forrnando um pacote de cêrca de 30 metros de espessura, achase sobrelevada a mais de 1.550 metros, indicando um desnivel ce pelo menos 700 metros, em relação aos sedimentos de Águas da Prata. Ao contrário dos sedimentos do lado interno do com- 
piexo, que mergulham para o centro, êstes, com pequeno ângulo, mergulham para fora.

b - No contacto do cristalino com as rochas alcalinas, notase que em quase todo o bordo, as rochas encaixantes estão topogràficamente mais altas, diminuindo de altitude à medida que se afastam do contacto

c - No bordo sul, os sedimentos capeados por lavas fonolíticas, acham-se topogràficamente mais baixos que o gnaisse encaixante, do qual estão separados pelo dique anelar do tinguaíto. O gnaisse, ao sul de Andradas, encontra-se também sobrelevado, ocorrendo em altitudes de mais de 1.450 metros.

$\mathrm{d}$ - Na área $\mathrm{E}$, em Pocinhos do Rio Verde, numa altitude de 900 metros, aflora no contacto entre tinguaíto e fenito, uma pequena faixa de arenito, intensamente perturbado. $\mathrm{O}$ arenito está incluso em tinguaíto e o fenito, no contacto, forma uma grande escarpa que se eleva a mais de 1.700 metros, em forma de crescente, com largura máxima de 10 quilômetros e comprimento de pouco mais de 20 quilômetros.

2 - Atividade vulcânica - Após ou durante o levantamento do embasamento cristalino teve início a atividade vulcânica, com alternância de fases explosivas e efusivas, durante a qual se depositaram, sôbre os sedimentos, camadas de brechas e tufos alternados com derrames de lavas ankaratríticas. Os testemunhos dessa atividade estão melhor expostos e conservados na faixa de forma semicircular entre Aguas da Prata e as proximidades da cidade de Poços de Caldas.

No vale do Quartel, rochas piroclásticas, ag] ornerados vulcânicos e lavas ankaratríticas formam um pacote de algumas centenas de metros. As rochas piroclásticas e lavas apresentam estratos, às vêzes perturbados, mas com mergulho. em geral, dirigido para o centro do maciço e são atravessadas por diques de tinguaíto. Vestígios de brechas e lavas são encontrados em quase todo o bordo interno do maciço, indicando que a atividade vulcânica, durante esta fase, havia abrangido a área atualmente ocupada pelas rochas alcalinas. 
Seguindo-se esta primeira fase, em que as lavas representam os tipos básicos da clã alcalina, houve uma segunda na area sul do complexo, formando as lavas fonolíticas, pelo extravasamento do magma, as quais com centenas de metros de espessura não possuem intercalaçc̃es de rochas piroclásticas.

3 - Subsidência da parte central - Observando-se o mapa geológico, chama atenção a grande uniformidade litológica, em que rochas consideradas de jazimento hipabissal, os tinguaítos, abrangem a maior área e certamente formaram-se após a atividade vulcânica. Apesar de existir mais de uma geração de tınguaítos, êstes apresentam grande uniformidade mineral e textural, indicando homogeneidade na composição química do miagma, o que permite supor certa contemporaneidade dos vários eventos geológicos. Esta uniformidade litológica, no entanto, dificulta a interpretação das várias fases da intrusão e cliferenciação das rochas.

Para o grande jazimento de Pilansberg, que em planta também se apresenta com forma circular, Shand (1929, $\mathrm{p}$. 148) admite a formação de uma rêde de canais entre blocos falhados que, por sucessivas atividades explosivas, abriram caminho para a ascenção do magma. Êste teria levantado os tufos e brechas, formando assim espêsso lacólito entre o embasamento cristalino e as rochas piroclásticas. Hipótese semelhante, foi também aventada por Freitas (1943, 1947 e 1951), para o caso de Poços de Caldas, onde o tinguaíto está geralmente em níveis topográficos mais elevados que seu correspondente plutônico. No entanto, a torma quase circular do maciço, limitado por uma seqüência de serras, constituídas de tinguaito com textura fluidal de mergulho vertical ou quase vertical e ressaltadas morfologicamente, formando um anel quase completo, bem como o fato de estar o embasamento cristalino sobrelevado ao redor do contacto ocorrendo em níveis topográficos mais elevados invalidam essa hipótese. (Fig. 11, perfil I; fig. 11A, perfis II e III; fig. 12, perfil IV e fig. 14, perfil VIII) 


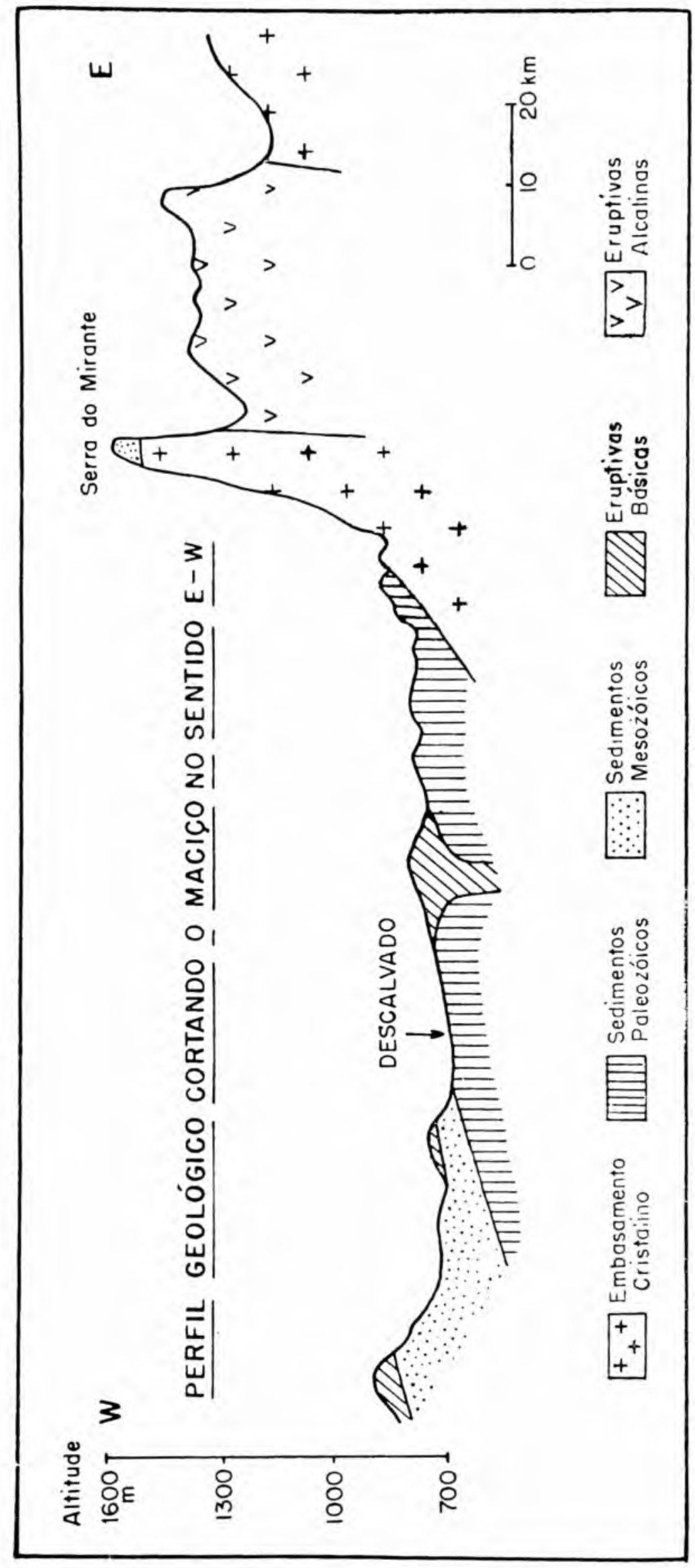

Fig. 11 - Perf:1 I. 


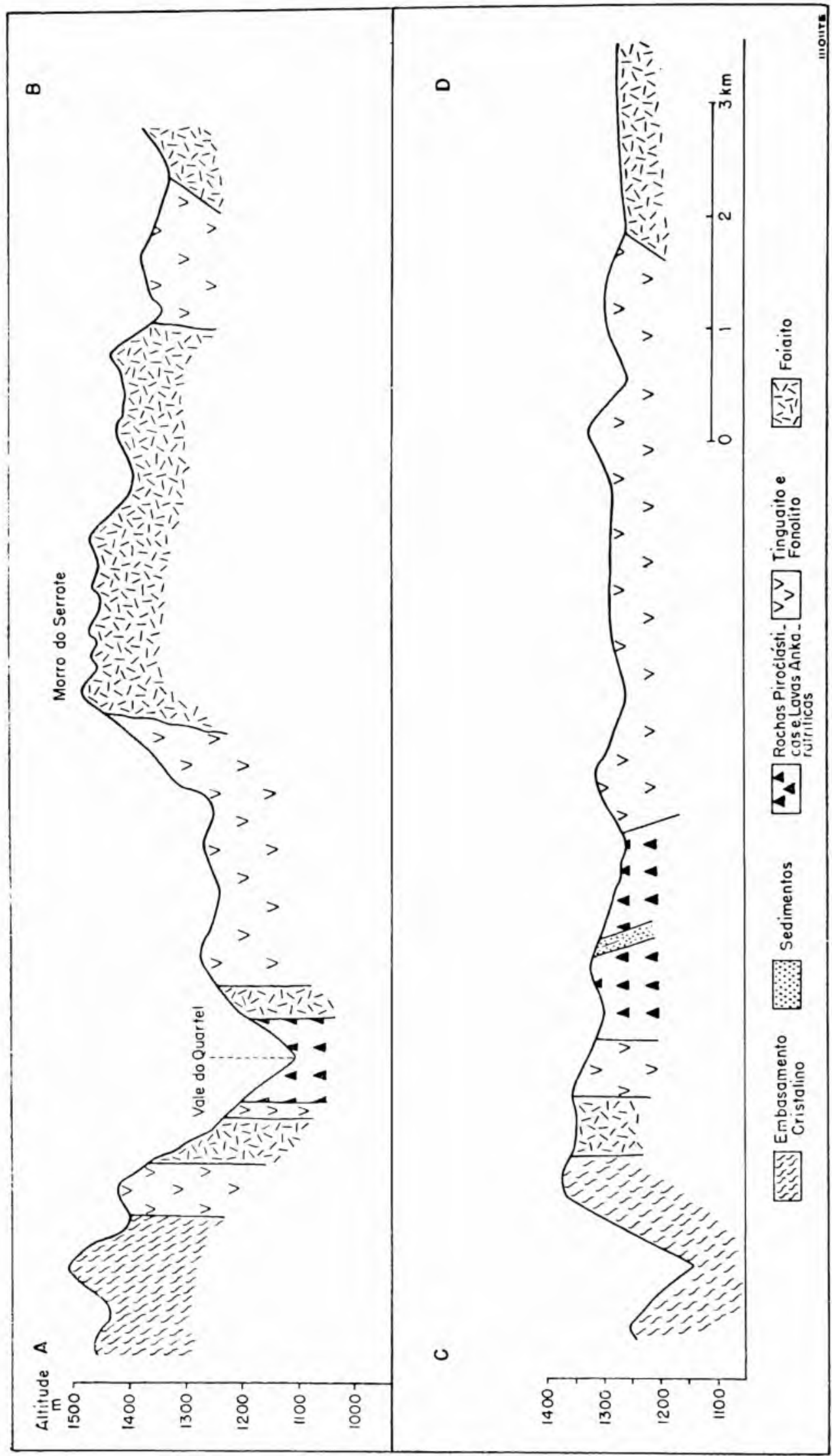

F g. $11 \mathrm{~A}-$ Perfis II e III. 


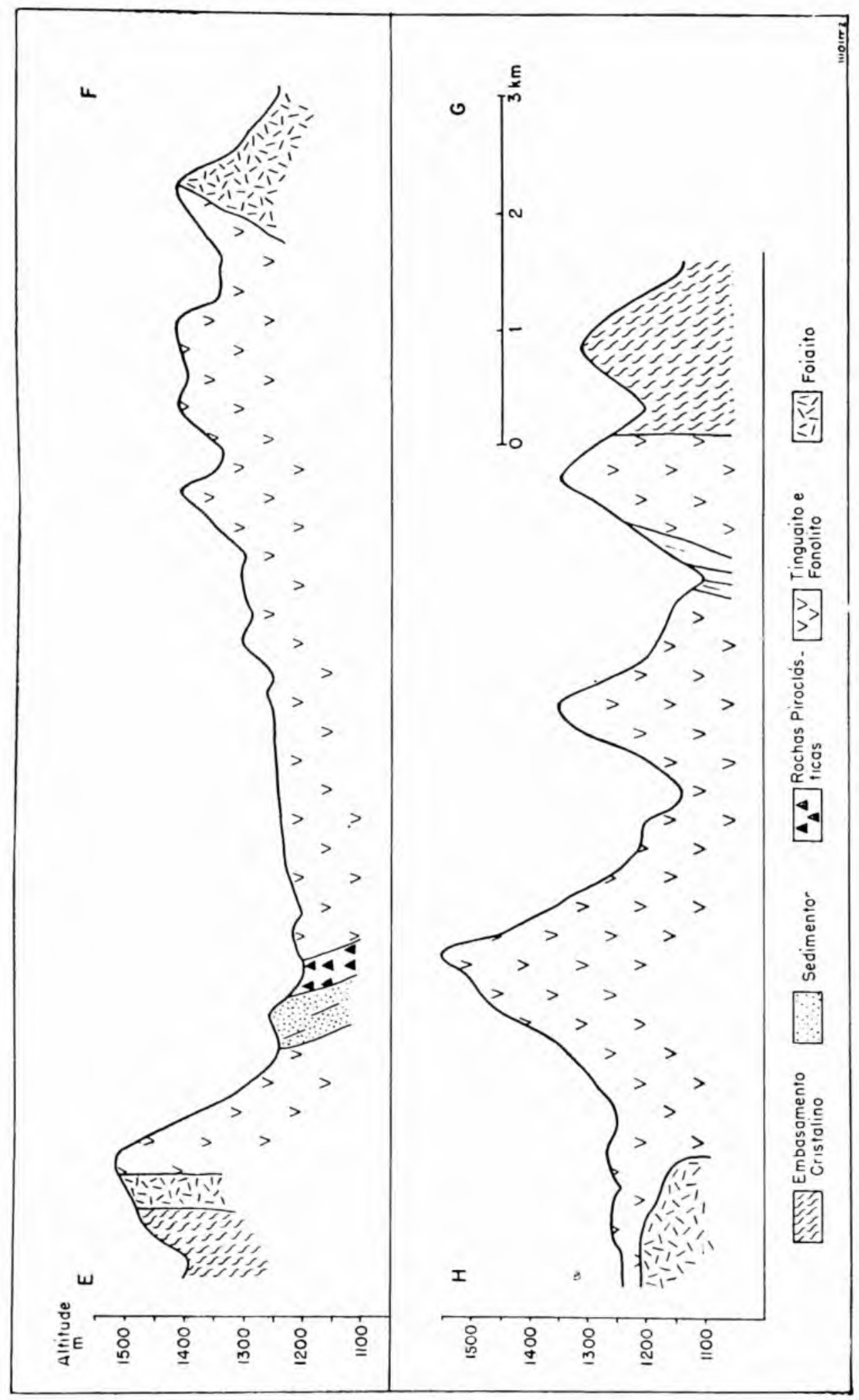

Fig. 12 - Perfis IV e V. 


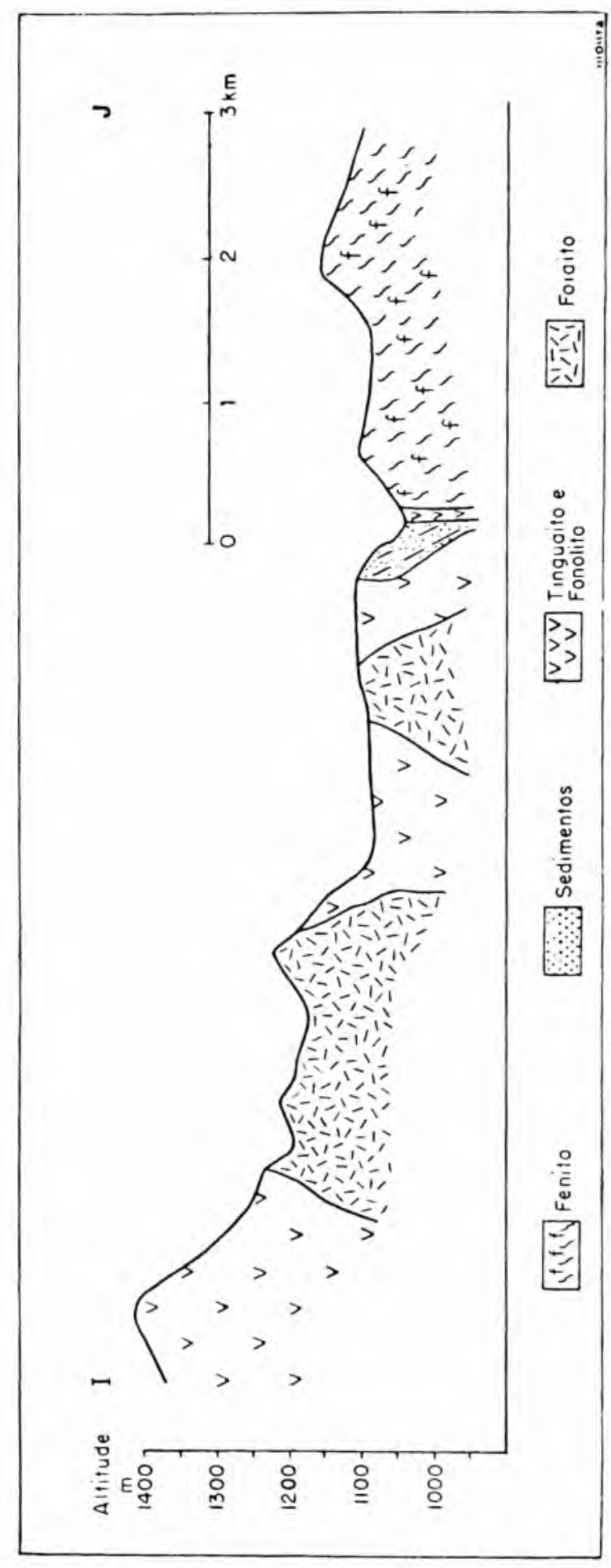

Fig. 13 - Perfil VI 


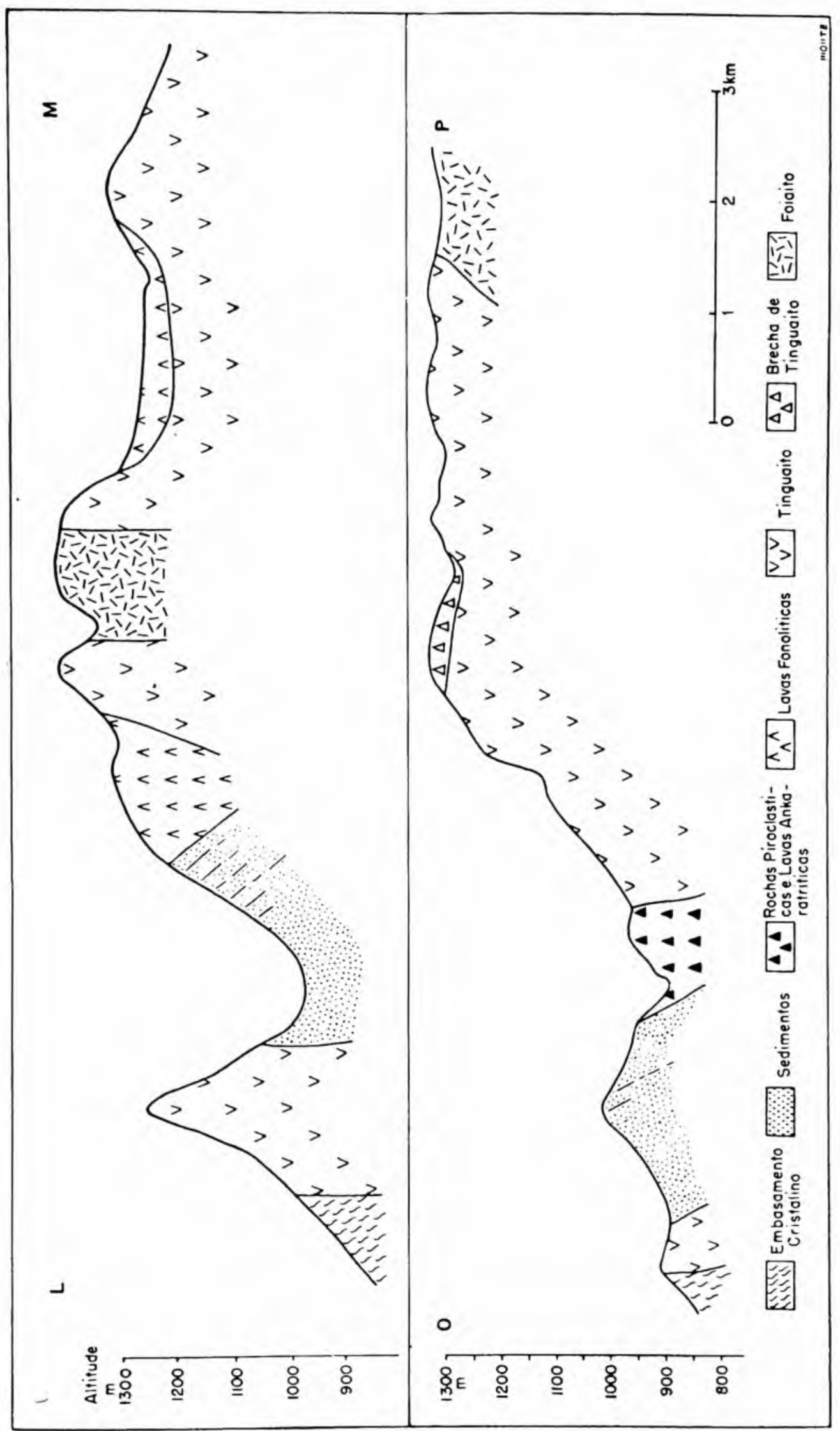

Fig. 14 - Perfis VII e VIII. 
Comparando-se as posições atuais dos sedimentos estudados por Björnberg (1959), que podem servir de níveis guias, nota-se que êstes se acham em posição variada e deslocados a altitudes diversas, situando-se ora sob brechas e lavas ankaratríticas, como em Aguas da Prata e Cascata, ora sob lavas fonoliticas como ao norte de Andradas e ainda entre e sôbre tinguaito como em Pocinhos do Rio Verde, ao sul de Laranjeiras e nas proximidades da barragem no rio das Antas. No lado externo do maciço, na serra do Mirante da Fartura, os sedimentos estão sobrelevados a mais de 200 metros em relação à posição dos sedimentos no planalto.

Por outro lado, como nāo há ocorrências de afloramentos do embasamento cristalino na área interna do maciço e apenas os sedimentos que sôbre êle se depositaram, deve-se admitir que após a atividade vulcânica houve abatimento da parte central, que foi compensada pela ascenção do magma. Os indícios clêste abatimento são os seguintes:

a -- A área central do maciço, com pequenas exceções, é formada exclusivamente por foiaíto e tinguaito. enquanto que nas proximidades do contacto com o embasamento ocorrem maiores variações litológicas. O mergulho das camadas de sedimentos, tufos, brechas e também das lavas é sempre dirigido para dentro do maciço, com mergulho variável, que é maior nas proximidades do dique anelar, fato êsse também assinalado por Billings (1943)

b - O gnaisse, acompanhando o contacto, está freqüentemente em posição mais elevada que o dique anelar (fig. 11A, perfis II e III; fig. 12, perfil IV)

c - Os sedimentos, brechas, tufos e lavas acham-se, em todo o bordo, em posição topográfica inferior ao embasamento (fig. 11 A, perfil II a fig. 14, perfil VIII)

d - No foiaíto do Aeroporto ocorrem xenólitos de lavas ankaratríticas que foram carreadas com a ascenção do rıagma.

e - No dique anelar sāo comuns xenólitos de rochas alcalinas, principalmente ao norte da cidade de Poços de Caldas, onde apresentam grande variação litológica. 
O abatimento do edifício vulcânico não foi no entanto, total, tendo parte servido de encaixante ao magma que originou o tinguaíto Mesmo no atual estágio de erosão são encontrados pequenos afloramentos de brechas e tufos, que foram perturbados com a intrusão do magma, como na área ao sul do morro do Serrotinho, em Cascata e ao norte do morro do Tarianduá, na área centro sul do planalto. As lavas fonolíticas, ao sul do maciço, também foram perturbadas com a intrusão co tinguaíto dos stocks dos morros do Mel e Tamanduá.

$\mathrm{O}$ abatimento central de rochas vulcânicas entre diques anelares foi assinalado e demonstrado por numerosos autores, entre os quais Kingsley (1931, p. 150), Modell (1936), Chapman (1940, p. 203) e Billings (1943 e 1945)

4 -- Ascenção do magma né̂́línico e formação de fonólitos, tinguaítos e foiaítos; êstes por diferenciação.

$O$ abatimento da parte central for compensado com a ascenção do magma nefelínico, que, na periferia subiu ao longo cie fendas circulares e radiais, enquanto que na parte central, graças à uniformidade litológica, não se notam feições estruturais e morfológicas que permitam hipóteses quanto à forma geométrica das intrusões. Ocorrem stocks, como os do morro cio Tamanduá, onde as direções das texturas fluidais acompanham o contacto com as lavas fonolíticas e o tinguaíto do morro do Mel que corta as lavas fonoliticas como dique radial. $\mathrm{Na}$ área centro-este são comuns vales assimétricos, semicirculares, talvez conseqüência das variações no mergulho das texturas fluidais. O tinguaíto servindo de teto precedeu a formação do fciaito. Contudo, existem em algumas áreas, diversos indícios que permitem supor que a diferenciação dêste foi contemporânea com a formação do tinguaíto. São os seguintes:

a - Na área Aeroporto-Serrote o contacto do foiaíto acompanha a textura fluidal do tinguaíto e é pegmatóide, emitindo pequenos pegmatitos que acompanham a textura fluidal do tinguaíto.

$\mathrm{b}$ - O tinguaito pode passar gradualmente a foiaito

c - Ocorrem diques de tinguaíto cortando foiaíto. 


\section{5 - Diques anelares}

Nos últimos 50 anos foram descritos diques anelares em numerosos lugares do globo. O trabalho clássico refere-se ao jazimento de Glen Coe, na Escócia, descrito por Clough et al. (1909) Posteriormente, foram identificados em vários países e freqüentemente associados a jazimentos de rochas alcalinas, sendo que nos Estados Unidos, no Estado de New Hampshire, ocorrem 15 complexos diferentes, (Billings, 1943) : Admite-se que a intrusão de um dique anelar é precedida pela formação de uma ou mais fendas circulares quase verticais. No entanto, existem dois problemas fundamentais: o primeiro refere-se às fôrças envolvidas para a formação das fendas circulares e o segundo à origem do espaço ocupado pelo dique anelar $\mathrm{O}$ conceito do mecanismo da intrusão de um dique anelar foi estabelecido por Anderson (1936) Admite êste autor uma câmara magmática a vários quilômetros de profundidade, com forma parabólica, tendo o magma, inicialmente, o mesmo pêsc específico que as encaixantes, estando por isso sujeito às mesmas pressões. No entanto, havendo um aumento da pressão da câmara magmática, as encaixantes estariam sujeitas a um sistema de tensões atuando através da superfície, que, nas proximidades da câmara magmática seria grosseiramente cônica, representado pelas linhas finas da fig. 15 que representam a intersecção dessas superfícies com o plano do diagrama. As tensões superimpostas, com o aumento da pressão do magma, seriam a causa da formação de uma série de fraturas, ao longo das quais o magma subiria formando os "conesheet"

Se mudarem as condições e a pressão da câmara magmática diminuir, as encaixantes estarão sujeitas a tensão. As fraturas de tensão em tais condições seriam paralelas ao contacto da câmara magmática e estão na fig. 15 representadas pelas linhas interrompidas. O mergulho divergente de tais fraturas seria muito pequeno, segundo Arderson, para ser ocuFado por um dique anelar Admite que o dique anelar segue a direção de ruptura representada pelas linhas grossas da fig. 


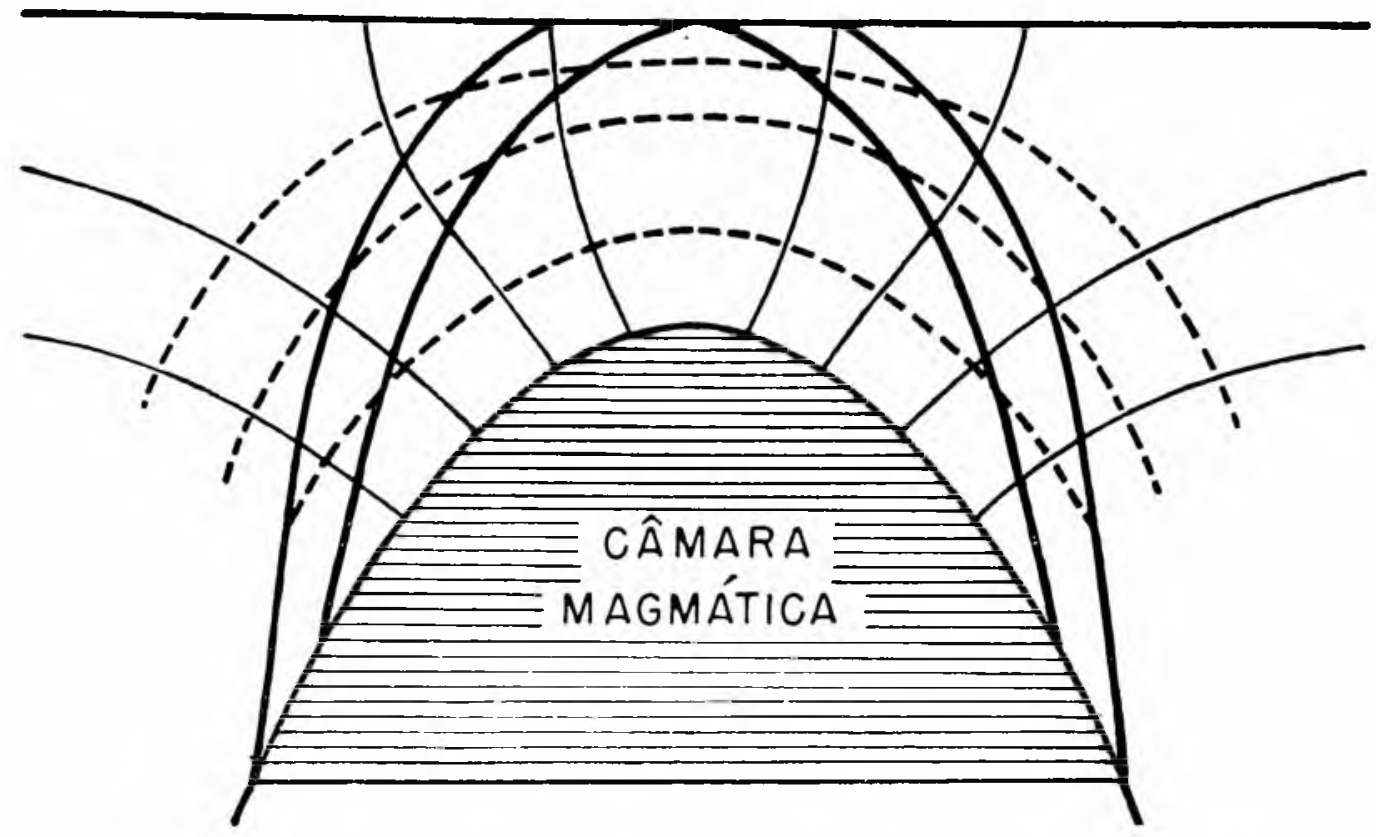

Fig. 15 - Dagrama da formação de diques anelares e "cons-sheet", segundo Andersory 1936.

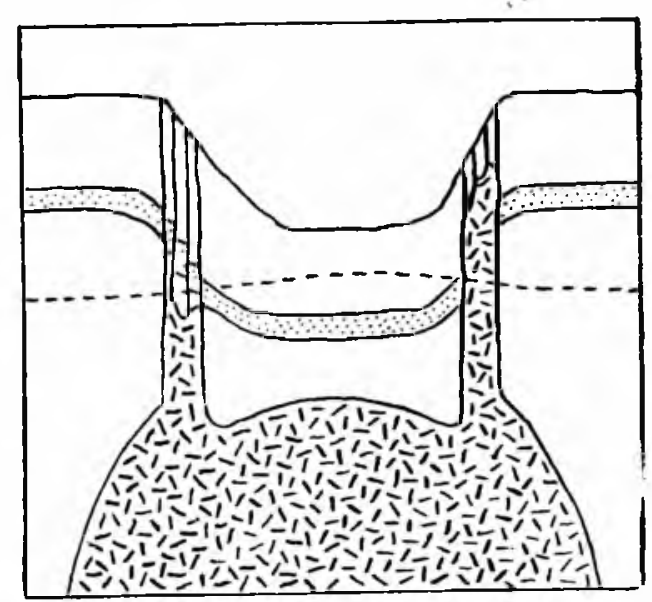

Fig. 16 - Diagrama Esquemático da formação de diques anelares verticais, segunáo Billings, 1945 . 
15. Um corpo limitado por tal sistema de fraturas seria parabólico e convexo para cima. Uma cavidade potencial entre a rocha encaixante e o bloco central em abatimento seria ocupada pela ascenção do magma. Posteriormente, a erosão faria ressaltar um corpo intrusivo, anelar em planta, mergulhando para fora. No entanto, numerosas observações em diques anelares, (Billings, 1945, Kingsley, 1931, p. 162), mostram que essa hipótese não é inteiramente satisfatória, pois os contactos externos dos diques anelares quase sempre são verticais ou mergulham para o centro do complexo. Diques anelares verticais são explicáveis se admitirmos uma intrusão controllada por uma zona circular de fraturas verticais, com largura comparável à do dique anelar (fig. 16, segundo Billings, 1945)

Como já foi assinalado no item 4 dêste capítulo, o magma nefelínico subiu na periferia do maciço ao longo de fendas circulares formando o grande dique anelar, quase completo, apenas não reconhecido no bordo $\mathrm{SE}$ do maciço Ressalta-se morfològicamente, delimitando quase todo o maciço e é acompanhado na metade norte por outro incompleto. No atual estágio de erosão a altitude do dique anelar é em parte função de sua espessura e posição com o gnaisse encaixante. Assim, a menor altitude e espessura são a $W$ de Águas da Prata, onde possuem poucos metros. No bordo W. a SW de Cascata, o dique anelar diminui ràpidamente de espessura e altitude, limitando-se no lado externo com o gnaisse sobrelevado e no interno com os sedimentos e rochas vulcânicas perturbadas que niergulham para o interior do complexo. Os contactos externos do dique anelar, quando expostos, são verticais ou quase verticais e nesse caso mergulham para o interior do maciço. O seu raio é de mais ou menos $16 \mathrm{~km}$, assemelhando-se ao de Franconia Quadrangle, em New Hamphire, que possui 7,5 milhas de raio (Billings, 1943) O dique anelar em quase todo o bordo externo limita-se com o gnaisse ou fenito, com exceção do bordo NE-N-NW onde ocorrem intrusões posteriores de foiaíto, lujaurito e chibinito. 


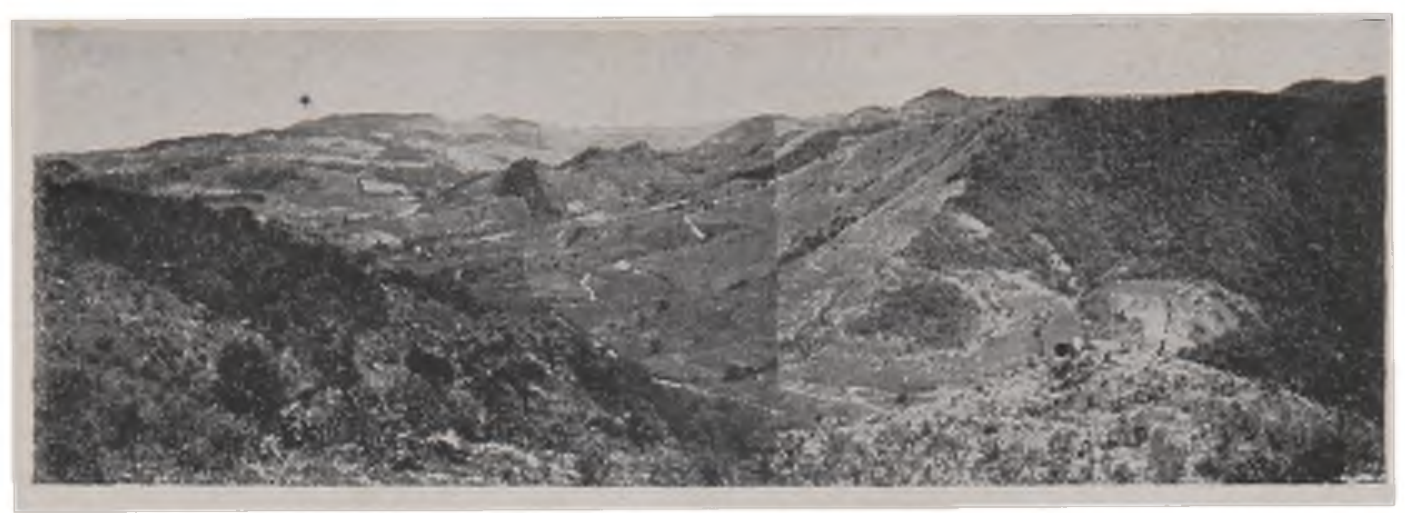

Fig. 17 - Vista do Vale do Quartel. Em primeiro plano, à direita, a superfície plana formada pelas brechas de tinguaíto. Nos fundos, à esquerda, a Serra do Mirante.

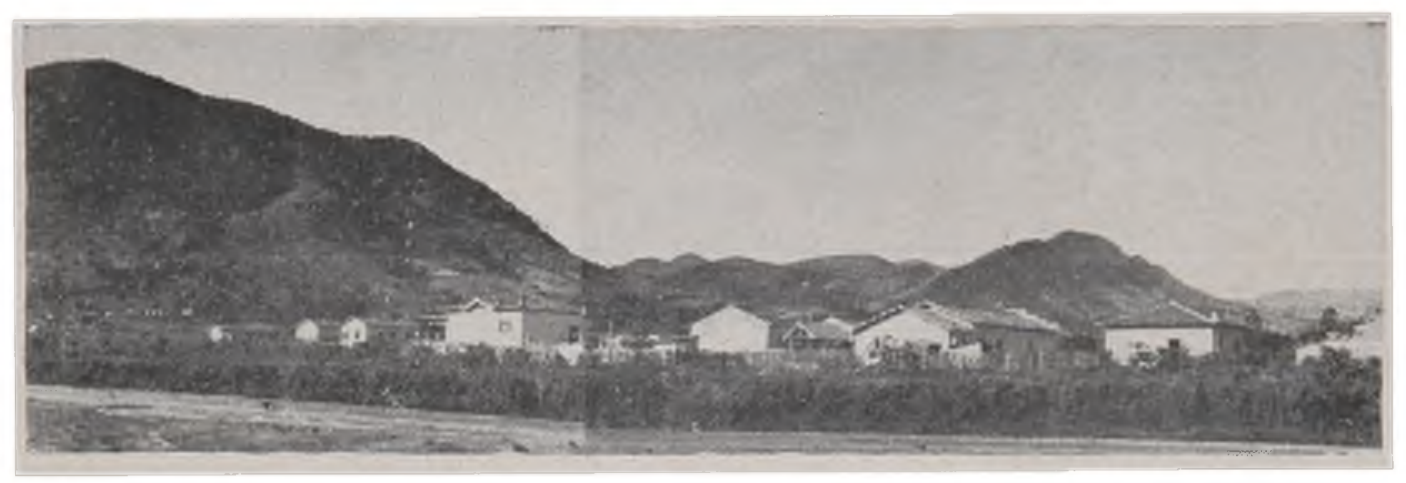

Fig. 18 - Serra de tinguaíto, ao norte de Andradas, formando o grande dique anelar.

O dique anelar é formado de tinguaíto, semelhante aos demais do maciço, tendo a diferenciá-lo a ocorrência de pequenos autólitos de microfoaíto, cujo tamanho geralmente não excede $3 \mathrm{~cm}$ de diâmetro. São formados de cristais de feldsrato e piroxênio com disposição radial. A quantidade dêsses autólitos varia de um afloramento a outro, havendo zonas de maior concentração. São comuns pontos pretos, milimétricos, formados de hauína e dispostos irregularmente. O melhor afloramento é o da pedreira Bortolan, à margem da rodovia Poços de Caldas-Cascata. No tinguaito ocorrem freqüentemente concentrações pegmatóides de foiaito, formando bolsões irígulares ou veios pegmatóides, assim como xenólitos que for ram levados com a ascensão do magma, fato êsse, também assinalado por outros autores na descrição de diques anelares, (Billings, 1945, p. 51, Kingsley, 1931, p. 162, Richey e Tho- 
maz, 1932, p. 784 e Clough et al., 1909, p. 633) No bordo $\mathrm{N}$ do planalto, na serra de Poços, numa faixa de algumas dezenas de metros, o tinguaíto assemelha-se a uma brecha maginática, tal a quantidade de xenólitos. A matriz com textura porfirítica engloba numerosos fragmentos, variando o tamanho desde menos de $1 \mathrm{~cm}$ até mais de meio metro. O contôrno dos xenólitos é anguloso ou arredondado e no contacto com a matriz observa-se nesta, às vêzes, côr diferente (bordo de reação?) e fenocristais de tamanho menor Os xenólitos são formados principalmente de foiaíto, às vêzes de granulação grosseira, microfoiaíto, tinguaíto, fonólito, piroxenitos e biotita-piroxenitos, de textura e granulação variáveis e raros fragmentos de arenito silicificado. Alguns xenólitos, aparentemente cie piroxenitos pegmatóides, são formados por agregados de cegerina com mais de $2 \mathrm{~cm}$ de comprimento e dispostos irregularmente entre massas foiaíticas. Em xenólitos de granulação fina, a aegerina e a biotita possuem disposição paralela e apresentam textura xistosa. Não observamos nenhum fragmento de gnaisse. A matriz é rica em cavidades preenchidas por calcita, agulhas de aegerina, prismas de natrolita e raramente neptunita e apofilita. Microscòpicamente a matriz apresenta grancie quantidade de nefelina, que forma fenocristais idiomorfos, com freqüente alteração parcial ou total para cancrinita ou natrolita, fenocristais de sanidina e pequena quantidade de cristáis de aegirina, geralmente hipidiomorfos ou xenomorfos, rodeados por uma massa microcristalina de feldspato, feldspatóides e aegerina. Em algumas lâminas a matriz apresenta textura protoblástica, na qual os fenocristais de nefelina estão partidos e dispostos paralelamente ao alinhamento dos minerais da matriz microtinguaítica, sugerindo movimentação num estado plástico. A presença de grande número de cavidades preenchidas por minerais primários e secundários da rocha e a freqüente alteração da nefelina em cancrinita e natrolita, bem como a ocorrência de calcopirita fazem supor atividade hidrotermal. Ocorrem xenólitos em todo o dique anelar, se bem que menos numerosos (fig. 19) 


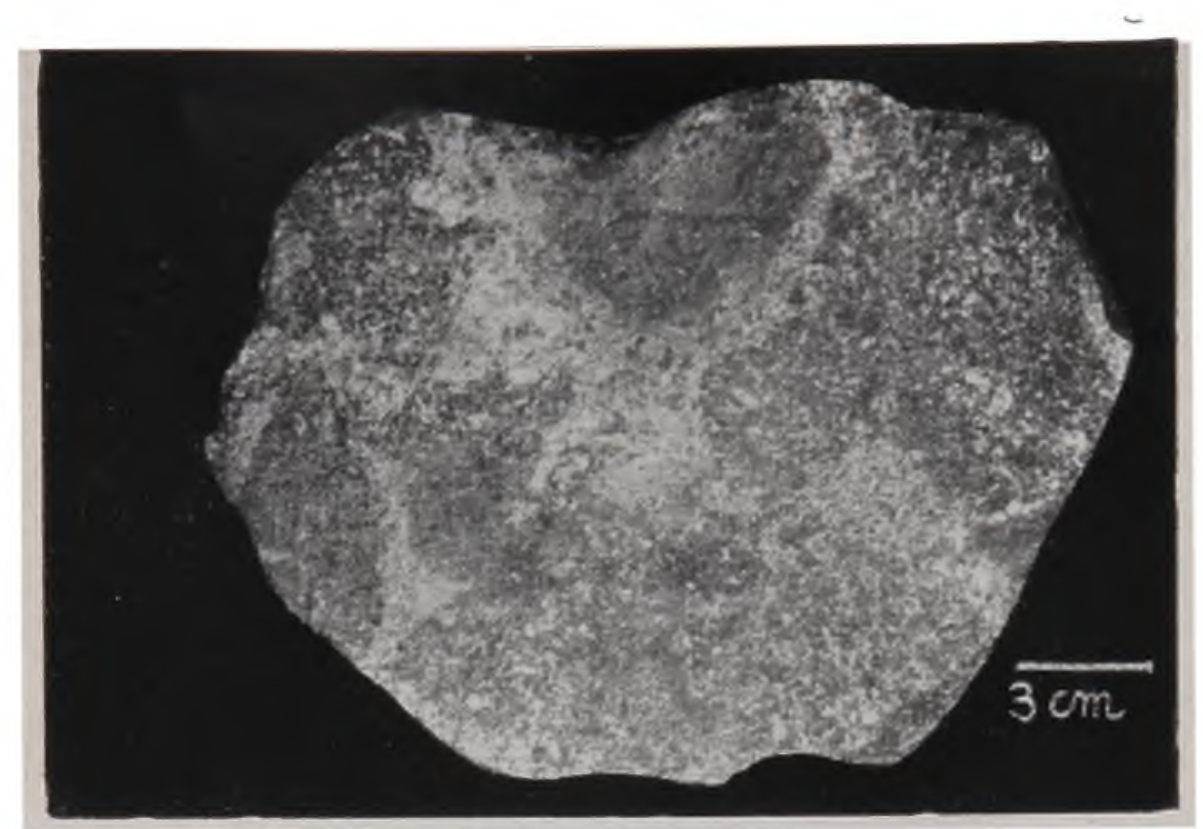

Fig. 19 - Tinguaíto rico em xenóilitos. Serra de Poços.

O mergulho da textura fluidal é para o interior do maciço. Ia serra de Poços para o interior do maciço afloram sòmente tinguaítos numa faixa de vários quilômetros e depois o foiaíto do Aeroporto. Torna-se assim difícil compreender como e porque acham-se concentrados, numa estreita faixa, xenólitos com tão grande variação de tamanho e litologia. Ocorrem rochas clesde superficiais até plutônicas, algumas de densidade elevada, como os piroxenitos ( $\mathrm{D}=3,2$ ), que não afloram na superfície. Devemos admitir um abatimento inicial no centro que possibilitou a formação e diferenciação das várias rochas encontradas como xenólitos. Em estágios posteriores de abatimento, na ocasião da ascenção do magma formando o dique anelar, foram englobados e carreados fragmentos de diferentes rochas situadas em diferentes níveis.

\section{6 - Formação de lujaurito, chibinito e foiaíto}

$\mathrm{Na}$ metade norte do maciço ocorrem intrusões posteriores de foiaíto, cortando e acompanhando o dique anelar. Igualmente posterior é a formação do lujaurito e chibinito, em forma de crescente, com a maior espessura numa direção normal à xistosidade do gnaisse. O chibinito, no contacto $\mathrm{NE}$, é separado do 
gnaisse por foiaíto também posterior ao dique anelar Às vêzes o chibinito parece ser intrusivo no foiaíto e em outros casos reconhece-se uma simples transição, desaparecendo as concentrações de eudialita e mudando gradualmente a textura traquitóide para equigranular

\section{COMPARATEO COM OUTRCS JAZIMENTOS DE ROCHAS ALCALINAS}

Dentre os grandes maciços alcalinos de Kola, Illimaussak, I iatiaia, Pilansberg e Poços de Caldas, os três primeiros são constituidos principalmente por rochas do tipo plutônico, enquanto que nos dois últimos ocorrem em grande área rochas vulcânicas (Pilansberg) e hipabissais (Poços de Caldas) No quadro abaixo, observa-se que os jazimentos do tipo plutônico apresentam grande variação litológica, aflorando junto à periferia as rochas mais ácidas, como granito e lestivarito, em Kola (Fersman, 1894), soda granito e nordmarquito, em Illimaussak (Ussing, 1911), nordmarquito em Itatiaia, (Lamego, 1936) e mais para o centro estāo representados tipos cada vez mais insaturados. Segundo Backlund (1933, p. 4), nos maciços alcalinos j!utônicos parece ser regra que a variação da composição quínico-mineralógica apresenta maior diversificação com o aumento do tamanhò da intrusão.

Quadro comparativo das rochas plutônicas

\begin{tabular}{|c|c|c|c|c|}
\hline 1. & 2 & 3 & 4 & 5 \\
\hline $\begin{array}{l}\text { Lestivarito } \\
\text { Umptekito } \\
\text { Chibinito } \\
\text { Chibinito } \\
\text { traquitóide } \\
\text { Foiaitos } \\
\text { Urtito } \\
\text { Ijolito }\end{array}$ & $\begin{array}{l}\text { Soda Franito } \\
\text { Nordmarquito } \\
\text { Augita-Sienito } \\
\text { Foiaito } \\
\text { Naujaito } \\
\text { Karkotokito } \\
\text { Lujaurito }\end{array}$ & $\begin{array}{l}\text { Nordmarquito } \\
\text { Sienito } \\
\text { Foiaito }\end{array}$ & $\begin{array}{l}\text { Sienito } \\
\text { Foiaitc }\end{array}$ & $\begin{array}{l}\text { Foiaito } \\
\text { Chibinito } \\
\text { Lujaurite }\end{array}$ \\
\hline $\begin{array}{l}3 \\
4 \\
5\end{array}$ & $\begin{array}{l}\text { - Peninsula d } \\
\text { - Illimaussak, } \\
\text { - Itatiaia, (La } \\
\text { - Pilansberg, } \\
\text { - Poços de Ca }\end{array}$ & $\begin{array}{l}\text { e Kola (Fersma } \\
\text { (Ussing, 1911) } \\
\text { (Shego, 1936) } \\
\text { aldas }\end{array}$ & an, in $B$ & 更 \\
\hline
\end{tabular}


Como Poços de Caldas e Pilansberg não podem ser consiclerados jazimentos plutônicos, seria talvez essa a causa da pequena variação litológica. O mecanismo da intrusão do maciço de Kola é muito complicado, principalmente na periferia, que representa as fases mais antigas da intrusão e na parte central do maciço ocorre um conjunto de "cone sheet" e diques anelares (Eliseev et al., 1937) Ussing (1911, p. 299) admite para Illimaussak a ascensão do magma pelo abatimento de blocos do teto sugerido pelos contactos verticais com as encaixantes e a existência, no augita-sienito, de grandes blocos de arenito, de até 200.000 metros cúbicos. Em nenhum dos três maciços, de Kola, Illimaussak e Pilansberg é feita menção de perturbações tectônicas nas encaixantes como conseqüência ca intrusão do magma al alino, como ocorreu em Poços de Caldas. Os grandes complexos calco-alcalinos da Africa do Sul, contemporâneos ao vulcanismo de Poços de Caldas, co1i. Erongo, Brandberg e Messum (Korn e IVartin, 1953, 54) são caracterizados por atividade passiva do magma que preencheu vazios formados pelo abatimento de blocos do teto.

\section{TECTÔNICA}

O escudo cristalino no sul do Brasil foi atravessado por numerosas intrusões alcalinas. Como pode ser visto na fig. 20 estas se estendem ao longo de duas direções principais. A primeira, no sentido $\mathrm{NE}$, pode ser subdividida em duas paralelas: uma, acompanhando a linha da costa com as intrusões de Cananéia, São Sebastiāo e ilhas próximas, Tinguá, Gericinó, Mendanha e Cabo Frio e a outra mais para o interior: Lages, Jacupiranga, Serrote, Ipanema e Itatiaia. A segunda direção, quase normal à primeira, no sentido NW, consta das intrusões de São Sebastião, Poços de Caldas, Araxá, Salitre e Serra Negra.

Guimarães (1947, p. 39) já chamou a atenção para a ocorrência dos jazimentos alcalinos, paralelos à costa, no Estado do. Rio de Janeiro. Freitas (1951, p. 86) associa as intrusões alcalinas com os fenômenos tectônicos responsáveis pela for- 


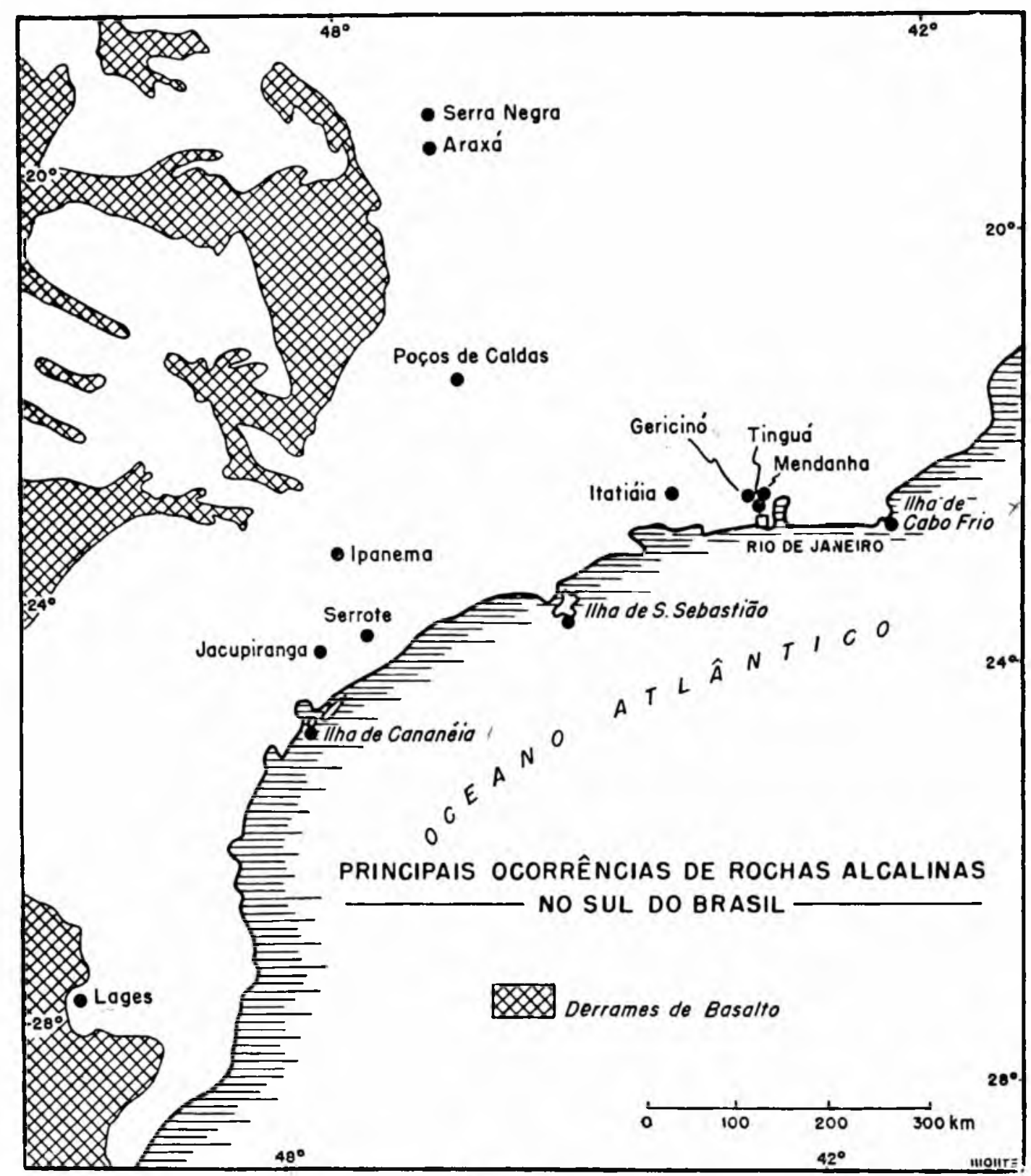

Fig. 20 .

mação das serras do Mar e da Mantiqueira. Em seu mapa tectônico do Brasil, Freitas (1951) considera de arqueamento do escudo cristalino no sul do Brasil as direções NW e NE. O arqueamento do escudo cristalino, produzindo tensões regionais em grande escala, seria o responsável pelo ciclo diastrófico que teria possibilitacio no Mesozóico a ascensāo do magma básico e posteriormente a formação dos maciços alcalinos. A existência de duas linhas de tensão, no sul do Brasil, uma pa- 


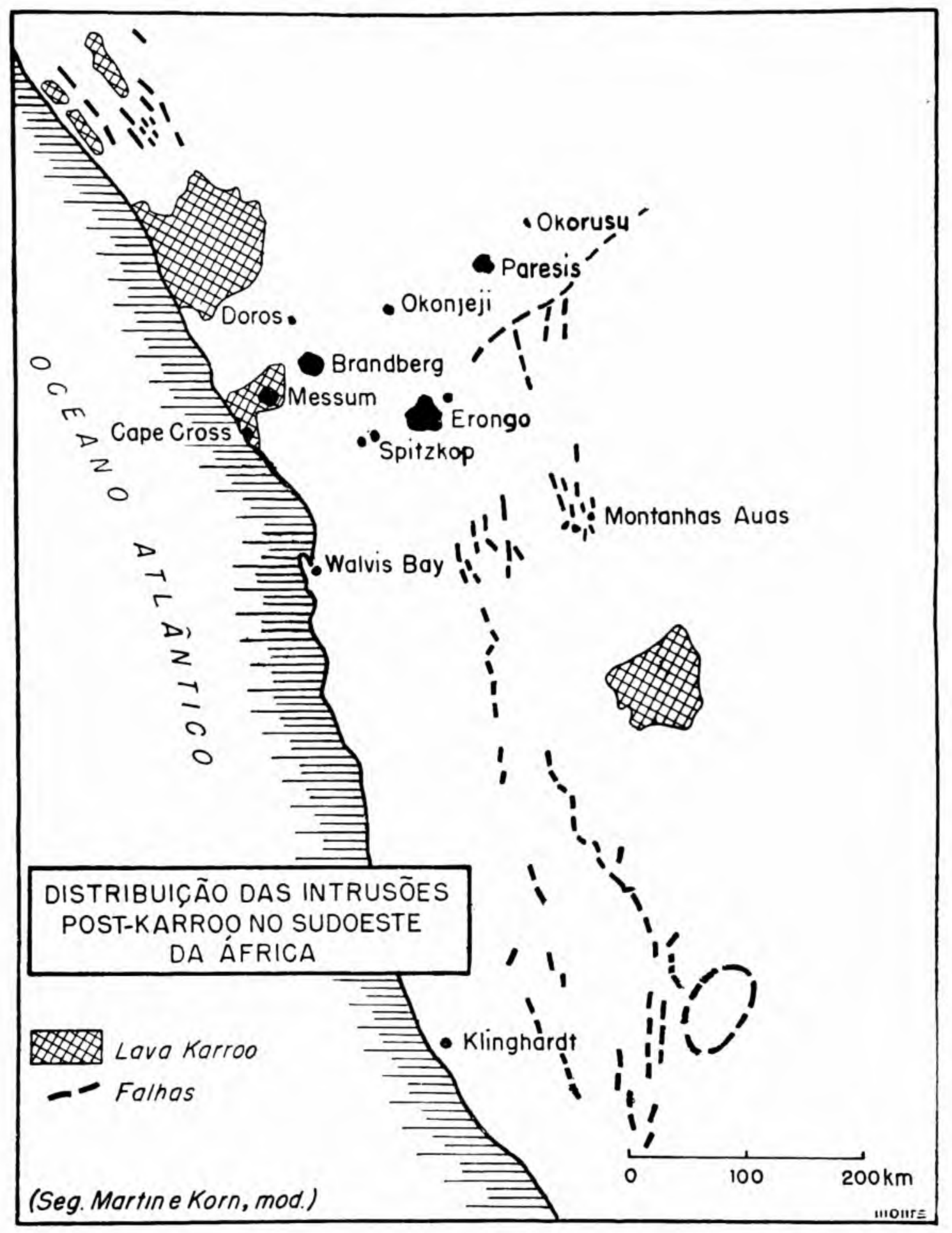

Fig. 21 . 
ralela à linha da costa e outra normal a primeira, que permitiram a subida do magma básico foi reconhecida por Leinz (1949, p. 54)

No Sudoeste da Africa, as direções de falha do Mesozóico ou posteriores, são paralelas à linha da costa e as grandes intrusões alcalino-graníticas, posteriores às manifestações básicas, alinham-se numa direção contínua de tensão, mais ou menos normal às direções de falha e em menor escala, paralelas à costa (fig. 21)

No capítulo referente ao mecanismo da intrusão alcalina, no jazimento de Poços de Caldas, já foi mencionado o levantamento, provàvelmente escalonado, de blocos do embasamen$t_{i}$ cristalino. Nos contactos com o tinguaíto, o gnaisse está geralmente fraturado e são freqüentes zonas de milonitização. Também no tinguaíto, perto do contacto, é comum um aumentc na freqüência das diaclases, principalmente no bordo $\mathrm{SE}$.

$\mathrm{Na}$ fig. 22 estão representados alguns dos elementos estruturais observados no maciço de Poços de Caldas. As várias observações são representadas pelos polos dos planos projetados em diagrama de Wulf. Os dados foram colhidos nos seguintes afloramentos:

1 - Gnaisse - Afloramento próximo ao contacto com o tinguaíto, na estrada de rodagem para São Sebastião da Grama.

2 - Fenito - Serra da Lagoa.

3 - Brecha vulcânica -- Barragem do Bortolan, no rio das Antas.

4 - Tinguaito - Pedreira Bortolan.

5 - Tinguaíto - Pedreira da Prefeitura.

6 - Tinguaito - Estrada de rodagem para Caldas, ao sul de Laranjeiras.

7 - Tinguaito - Corte na estrada de rodagem Poços de Caldas-Andradas.

8 - Lava fonolítica - Idem. 


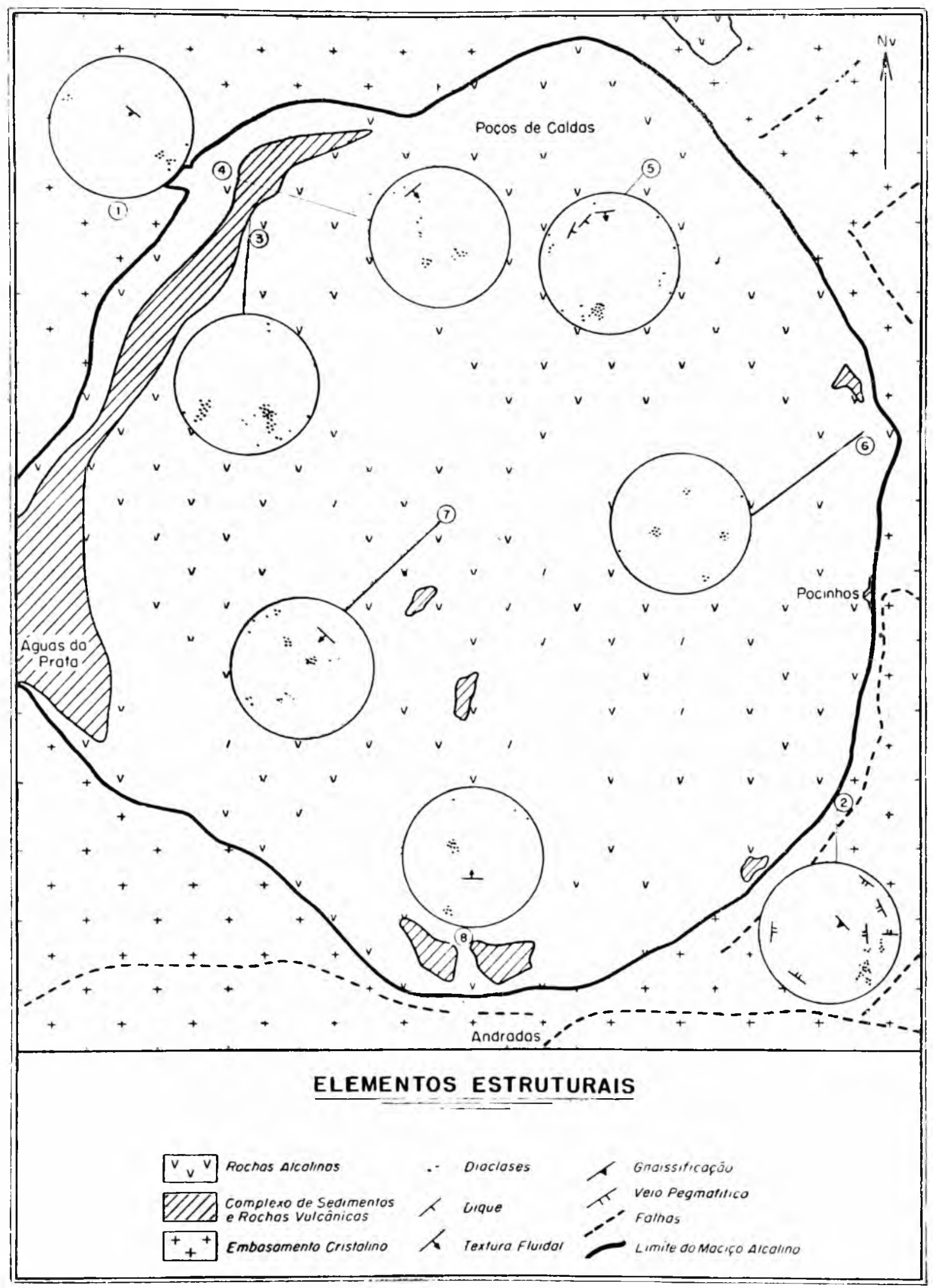

$F:$. 22. 


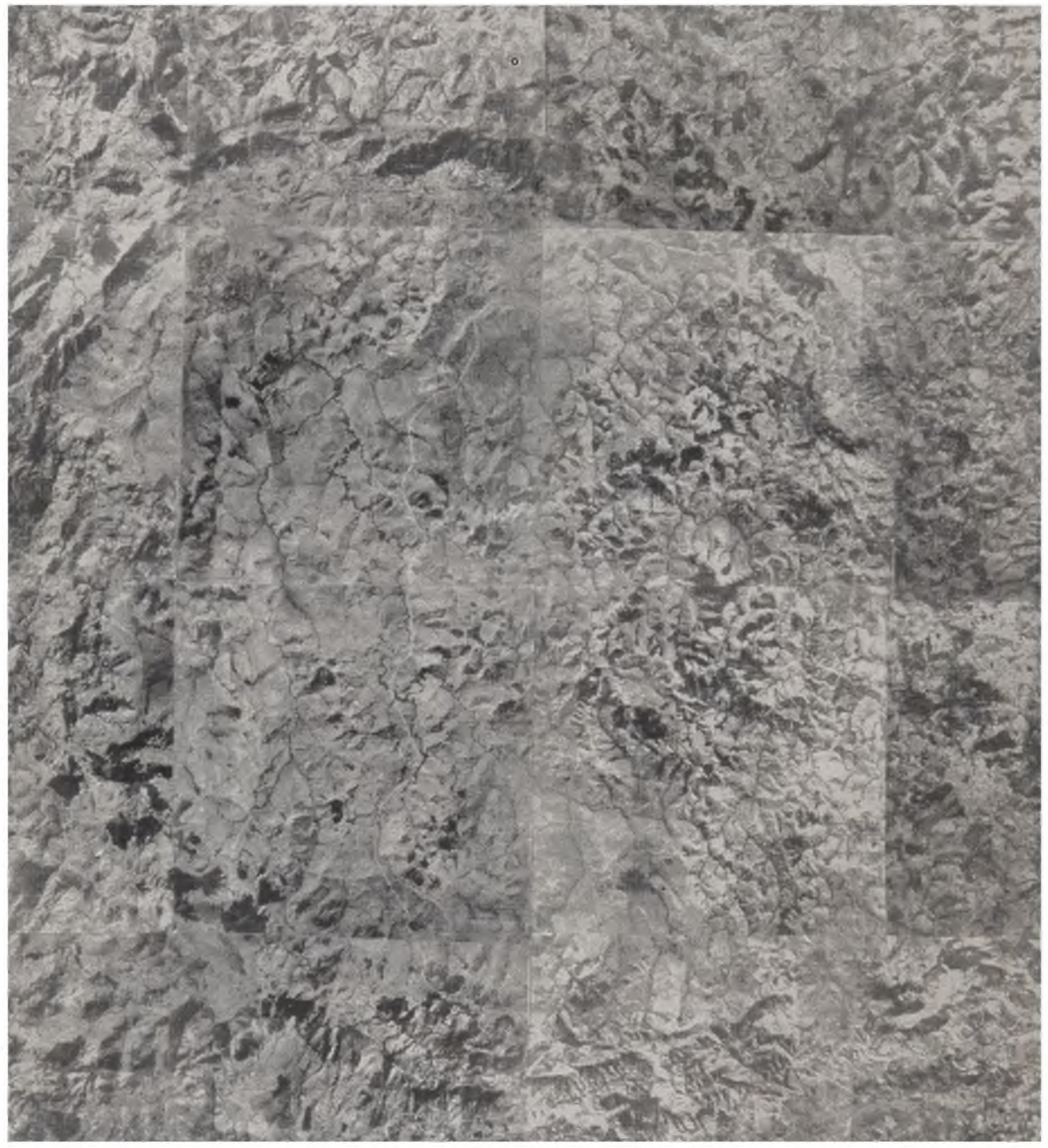

rig. 23. 
No gnaisse e no fenito (projeções 1 e 2) predominam as diaclases de tensão, perpendiculares à xistosidade. No tinguaito do dique anelar (projeções 4,5 e 6 ) ocorrem, além das diaclases de tensão, as longitudinais. A projeção das diaclases na brecha (projeção 3) mostra dois máximos de freqüência, um normal à direção dos afloramentos da brecha e outro paralelo. Nas diaclases do tinguaíto, na área centro sul, predominam também as longitudinais e as de tensão.

E' provável que sejam íntimas as relações entre as direções de diaclases e a drenagem dos rios no planalto. Observando-se a redução do mosáico do levantamento aéreo (fig. 23) notam-se duas áreas mais ou menos distintas em sua feição morfológica. A maior, apresentando estágio de maturidade, ocupa a área $\mathrm{N}-\mathrm{W}-\mathrm{S}$ do maciço e mostra drenagem anelar, ao passo que a menor, na área $\mathrm{E}$, com relêvo entre juventude e maturidade, possui um sistema misto de drenagem radial e anelar

O rio principal, o das Antas, nasce perto do bordo $\mathrm{SE}$ e dirige-se para NW atravessando todo o complexo. Na área ocupada pelo tinguaíto e foiaíto o seu curso é em ângulos quase retos, ora para $\mathrm{NE}$ e ora para NW, direção essa também seguida pelos seus afluentes. A erosão remontante, no atual curso do rio das Antas, perto do contacto com o gnaisse, parece ser fenômeno de captura, pois o curso normal, ao cortar o dique anelar seria o do rio do Peixe.

Após a formação do dique anelar ocorreram falhamentos em grande extensão. Os indícios de que êstes falhamentos são posteriores às atividades magmáticas são principalmente morfológicos:

a - No bordo $\mathrm{S}$, tangenciando o dique anelar, corre um grande vale no sentido $\mathrm{E}-\mathrm{W}$ desde a $\mathrm{E}$ da cidade de São João da Boa Vista até Santa Rita de Caldas, assemelhando-se a um "graben" E' limitado ao sul pelo gnaisse falhado em blocos escalonados, com escarpas abruptas, diagonais à xistosidade, formando uma linha quase contínua. No tôpo da escarpa há lima superfície suave, que mergulha para o sul e os riachos 
Gue vão ter ao vale apresentam vales suspensos. O "graben" no seu lado norte é menos regular, formando reentrâncias, como a serra do Óleo, onde são comuns vales suspensos e em parte a serra do Caracol. Os indícios de que êstes falhamentos são posteriores ao dique anelar são revelados pelos riachos, que com grande gradiente, conseguiram cortar o dique anelar, onde a sua espessura é menor Atualmente exercem grande trabalho erosivo, nos sedimentos pouco consolidados e lavas fonolíticas alteradas, desenvolvendo um sistema de drenagem dendrítica e capturando as cabeceiras dos riachos do plaralto.

b - Outra direção de falhamento é N-S, tangenciando o maciço no bordo $W$ É também ressaltada morfològicamente, cortando diagonalmente a xistosidade.

c - Na fig. 23 nota-se, no quadrante $\mathrm{NE}$ do maciço, uma linha contínua de vales, que se ressaltam morfològicamente, servindo de divisor de duas áreas morfológicas distintas. Esta linha continua para fora do maciço, formando a serra da Picada, cuja linha de escarpa de falha é quase normal à xistosidade do gnaisse.

$\mathrm{d}-\mathrm{O}$ escarpamento do gnaisse no sentido N-S, a $\mathrm{E}$ da cidade de Caldas, bem como o escarpamento no fenito, acompanhando o contacto $\mathrm{SE}$ com o tinguaíto sugerem pertencer a falhamentos posteriores à intrusão alcalina.

\section{MAPA GEOLóGICO}

O levantamento geológico por nós elaborado foi feito com auxílio de mapas topográficos nas escalas de 1:10.000 e 1:25.000. As observações de campo, que abrangem mais de 2.000 afloramentos foram transcritas em mapa na escala de 1:50.000. Como o mapa topográfico não abrange pequena área a W de Aguas da Prata, o contacto da intrusão alcalina e as encaixantes dexou de ser representado.

Em vários lugares, tanto nas rochas alcalinas como no embasamento cristalino, observamos desvios na agulha da bússola de até $180^{\circ}$. quando em contacto com a rocha. 


\section{Gnaisse e fenitos}

Os contactos da intrusão alcalina e as encaixantes, sempre que possível foram acompanhados e na ausência de afloramentos observamos e anotamos o aparecimento de grãos de quartzo no solo. Contactos nítidos, nos quais se observam as duas rochas lado a lado e no estado fresco, são raros. O gnaisse está muitas vêzes brechado ou, pelo diaclasamento intenso, muito alterado .

\section{Sedimentos}

No mapa geológico, os vários tipos de sedimentos estão mareados em conjunto. Êstes compreendem camadas argilo-arenosas, com estratificação horizontal e arenitos silicificados com estratificação cruzada. Os sedimentos da base do pacote, formados pela alternância de leitos arenosos e siltosos, com intercalações de folhelhos, afloram apenas a $\mathrm{E}$ da cidade de Águas da Prata e ao norte de Andradas. A melhor exposição dos sedimentos da base é ao longo da estrada de rodagem que sobe heirando uma elevação de quase 200 metros, ligando Águas da Prata à fazenda Refúgio. As camadas estão perturbadas de sua posição inicial, mergulhando para o interior do maciço, com ângulo menor de $20^{\circ}$ e atravessadas por pequenos diques alterados. Na cidade de Águas da Prata, situada na base da elevação, afloram principalmente os arenitos do tôpo do pacote, deslocados por falhamentos, provàvelmente NS. Num afloramento ao norte da cidade, nas proximidades do parque municipal, sedimentos argilosos foram cortados por intrusão de tinguaito, no qual notamos agregados centimétricos de feldspato e nefelina, assemelhando-se a pseudo-leucita. Os demais afloramentos de sedimentos desta área são sempre de arenitos que acompanham o dique anelar e são cobertos por rochas piroclásticas e lavas. Às vêzes, os arenitos apresentam indícios de retrabalhamento com adição de material provàvelmente vulcánico, o que pode ser observado na fazenda Cachoeirinha e num afloramento nas proximidades da estrada de ferro entre Cas- 
cata e Poços de Caldas, onde delgadas camadas de arenito estảo intercaladas com brechas alteradas. No rio das Antas, nas proximidades da cachoeira do Ozório, os arenitos limitam-se com o tinguaíto do dique anelar e brechas. Formam uma faixa, em forma de cunha, que penetra no dique anelar e foram soerguidos com a ascenção do magma.

No afloramento an sul de Laranjeiras o arenito silicificacio está englobado no dique anelar e mergulha para o interior co maciço. Os sedimentos do sul do planalto foram intensamente perturbados, sobretudo nas proximidades do dique anelar

\section{Rochas vulcânicas}

Como rochas vulcânicas estão mapeados tuíos, brechas, aglomerados vulcânicos e lavas ankaratríticas. $\mathrm{Na}$ faixa $\mathrm{N}$ NW-W do complexo ocorrem as maiores variações litológicas, formando camadas alternadas, comumente decompostas, o que impede a delimitação correta das várias rochas.

Tufos e brechas - As rochas piroclásticas são constituídas principalmente por brechas e em menor escala por tufos. A estratificação em vários afloramentos de brecha sugere retrabalhamento e deposição posterior Entre Aguas da Prata e Cascata as brechas são de côr castanho escura, predominando fragmentos de gnaisse, diabásio e sedimentos e no cimento ocorre quartzo arredondado em grande quantidade. Tufos com intercalações de bombas vulcânicas aparecem na estrada de ferro, um pouco acima do cruzamento com a estrada para a fonte Platina. De Cascata, até as proximidades de Poços de Caldas, as brechas, quando frescas, são de côr verde e, em geral, com poucos fragmentos.

$\mathrm{Na}$ área central do maciço há dois afloramentos decompostos formados de rochas vulcânicas. O primeiro, é cortado pela rodovia Poços de Caldas-Andradas e consta de camadas alternadas, constituidas de material de granulação fina, com quart¿o rolado e cimento argiloso. Trata-se provàvelmente de um 
antigo lago que recebeu contribuição de tufos vulcânicos e sedimentos retrabalhados. O segundo, um pouco a SE do primeiro, situado numa posição topográfica mais elevada, consta de brechas alteradas estratificadas. Nos dois afloramentos observa-se que estas rochas foram perturbadas pela intrusão de tinguaíto. A pequena área formada de brechas alteradas, nas proximidades do contacto $\mathrm{SE}$ com o fenito, foi também cortada por tinguaíto, bem como os pequenos afloramentos ao norte de Pocinhos do Rio Verde.

Aglomerados vulcânicos e lavas ankaratríticas - No vale do Quartel aparecem bons afloramentos de lavas ankaratríticas, geralmente aglomeráticas. Estão quase sempre associadas aos aglomerados vulcânicos, que sĩ constituídos de fragmentos de lavas, cimentados pelos próprios minerais da lava fragmentados. Pequenos afloramentos de lavas ankaratríticas alteradas ocorrem entre Cascata e a cachoeira do Ozório e também ao sul de Laranjeiras, nas proximidades do contacto com o gnaisse.

\section{Lavas fonolíticas}

As lavas fonolíticas, em geral intemperizadas formam um relêvo suave no sul do maciço. Bons afloramentos ocorrem sòmente em alguns cortes na estrada de rodagem. Os contactos com o tinguaíto foram demarcados apenas no dique anelar, e nos morros do Mel e do Tamanduá, sendo os demais inferidos devido a ausência de afloramentos.

\section{Tinguaítos e fonólitos}

A arbitrariedade do critério na individualização dessas duas rochas, que mostram freqüentemente passagem gradual de um tipo a outro, já foi mencionada na p. 18. Formam a maior parte do maciço e apreșentam algumas variações como o analcita-fonólito e tinguaíto com pseudo-leucita. As áreas de brechas de tinguaíto, do bordo SE, são irregulares e os contaclos com o tinguaito sä̀ pouco nítidos. 


\section{Rochas plutônicas}

Foram observadas as relações tinguaíto e foiaíto e sempre que possível os contactos foram seguidos.

$\mathrm{O}$ contacto do foiaíto com o tinguaíto, ao $\mathrm{N}$ do aeroporto segue geralmente a direção $\mathrm{NE}$, acompanhando de certo modo a crista das elevaçōes. Neste contacto há bons afloramentos no campo e nas pedreiras em exploração, que permitem estabelecer as relações entre as duas rochas. Mais para o norte, na base da serra do Selado e ao longo do ribeirão do Charque o foiaíto é de granulação fina, aparentando passagem gradual para o tinguaíto. Nas pedreiras do lado esquerdo da estrada para Campestre, aflora microfoiaíto, com zonas pegmatíticas e bolsões pegmatóides. O contacto sudeste desta larga faixa de foiaíto obedece também direção geral NE, mas é pouco nítido, dificultado pela passagem quase gradual para tinguaíto.

$\mathrm{Na}$ área do Serrote, o foiaíto apresenta-se como um corpo quase circular, tendo em seu interior afloramentos de tinguaíto. No contacto $\mathbf{E}$ o foiaíto, de granulação grosseira, corta o tinguaíto em vênulas e pequenos pegmatitos acompanhando a textura fluidal do tinguaíto e a N-NW o foiaíto corta o tinguaíto e tinguaíto com pseudo-leucita. Êste, perto das minas de zircônio, pude apresentar granulação grosseira, assemelhando-se a foiaíto com pseudo-leucita. Nas proximidades do contacto, os pseudomorfos diminuem de tamanho, tornando-se reconhecíveis às vêzes, apenas no tinguaíto decomposto. O contacto ao sul é comumente uma zona de microfoiaíto. N'as duas rochas sāo freqüentes agregados de eudialita.

Nas demais ocorrências de foiaíto da área interna do maciço, os contactos com o tinguaíto, devido à cobertura vegetal, em geral são inferidos.

$\mathrm{Na}$ parte $\mathrm{N}$ do complexo, o lujaurito apresenta passagem gradual para chibinito. Com o foiaíto os contactos do chibirito não puderam ser observados pela ausência de afloramentos, mas os contactos lujaurito e foiaíto estão razoàvelmente demarcados. 


\section{RECURSOS MINERAIS}

As principais riquezas minerais do planalto de Poços de Caldas são representadas pelas jazidas de bauxita e zircônio uranífero. Ültimamente foram descobertos e estão sendo prospectados os depósitos de tório e terras raras do morro do Ferro. Bauxita - Jazidas de bauxita foram descobertas nos últimos vinte anos (Teixeira, 1937) e atualmente está sendo incrementada a prospecção por várias companhias. As maiores jazidas estão situadas na metade norte do complexo e são formadas principalmente a partir da decomposição dos tinguaítos.

Minerais de zircônio - Nos estudos petrográficos das rochas alcalinas do maciço não foi descrito o zircão como mineral pririnário. Nos foiaítos e tinguaítos sāo comuns como minerais zirconíferos primários a eudialita, lavenita, rosenbuschita, giannetita e pennaita, êstes dois últimos primeiramente descritos por Guimarães (1948) Os minerais zirconíferos teriam sido destruídos por processos hidrotermais e posteriormente precipitados em fendas sob forma de óxidos e silicatos de zircônio (Franco, 1947)

No minério zirconífero foi constatada a presença de urânio com teor médio, em geral, de 0,5 por cento de óxido de urânio. Num levantamento aéreo, as maiores anomalias radioativas estão em geral associadas a depósitos de minérios de zircônio, com exceção do morro do Ferro, onde as anomalias resultam da ocorrência de minérios de tório (Oliveira, 1956) As maiores jazidas zirconíferas são as do Serrote, Taquarí e Pouso Alegre e acham-se nas proximidades do contacto foiaíto-tinguaíto. Compreendem depósitos primários (vieiros) e secundários (aluviais e eluviais) Os vieiros, cortando rochas profundamente intemperizadas, são formados por zircão, baddeleyta e caldasita, que é uma mistura formada pela associção de óxido e silicato de zircônio. Nos depósitos secundários predominam concreções mamelonares, constituídas úe óxidos de zircônio e chamadas "favas"

A área NE do planalto formada principalmente por lujaurito e chibinito, rochas ricas em eudialita, apresenta também 
fortes anomalias radioativas. No entanto, fenômenos de atividade hidrotermal parecem estar ausentes, pela ausência de depósitos zirconíferos.

\section{RESUMO}

O presente trabalho apresenta um estudo da geologia do maciço alcalino de Poços de Caldas. Pela sua área, que é da crdem de 800 quilômetros quadrados, é considerado um dos maiores complexos formados exclusivamente por rochas nefelinicas. Possui forma elíptica, com $35 \mathrm{~km}$ no sentido NE-SW e $30 \mathrm{~km}$ no sentido NW-SE e ainda um stock de foiaíto, com cêrca de 10 quilômetros quadrados. A W limita-se com a bacia sedimentar do Paraná e a E cor os contrafortes da serra da`Mantiqueira. O maciço está encaixado entre granito e gnaisse, que nos quadrantes SE e em menor escala no quadrante NW. foi afetado metassomàticamente pelo processo de fenitização, principalmente ao longo da direção de xistosidade. No quadrante NW o fenito é de côr cinza esverdeada e no quadrante SE sua côr é vermelha.

O maciço é constituído principalmente por rochas nefelínicas, tinguaítos e foiaítos, mas possui em seu interior rochas anteriores à intrusão alcalina. São sedimentos e rochas vulcânicas formadas por tufos, brechas, aglomerados e lavas ankaratríticas. Os sedimentos acompanham o contacto com o Enaisse e afloram em maior extensão nas áreas $\mathrm{W}$ e $\mathrm{S}$ do complexo. A base do pacote sedimentar consta de camadas argilo-arenosas, com estratificação horizontal e o tôpo é formado por arenitos com estratificação cruzada. Acham-se perturbados e mergulham, no geral, para o interior do maciço. Sôbre os sedimentos foram depositados brechas, tufos e lavas, que formam uma faixa contínua no bordo N-W Nas brechas vredominam fragmentos de sedimentos, gnaisse, diabásio e lavas. O cimento é rico em quartzo detrítico arredondado. $\mathrm{Na}$ diagênese, a ação de soluções hidrotermais é evidenciada pelo aparecimento de biotita autígena e um feltro de microcristáis de aegerina e apatita. No cimento, a calcita secundária é 
muito comum, chegando a substituir parcial ou totalmente o quartzo. As lavas ankaratríticas, quase sempre em espêssos derrames, formam freqüentemente aglomerados. Vestígios de rochas vulcânicas são encontrados em quase todo o bordo interno, indicando que a atividade vulcânica abrangeu grande área. Após essa atividade vulcânica formaram-ı́e fonólitos, tinguaítos e foiaítos, com freqüentes passagens de um tipo de rocha a outro. Os tinguaítos constituem a maior área do complexo e apresentam grande uniformidade. Em algumas áreas principalmente nas proximidades de Cascata afloram variedades com pseudo-leucita e analcita. Os foiaitos são intrusivos no tinguaíto, mas a "mise-en-place" provàvelmente deu-se contemporaneamente, sugerida pela passagem, não raro, gradual de uma rocha a outra.

Além dos vários tipos de foiaítos, equigranulares e traquitóides, afloram em pequena extensão lujaurito e chibinito. Para o mecanismo da intrusão é admitido o levantamento de blocos do embasamento cristalino que precedeu a atividade vulcânica. Durante ou após a atividade vulcânica deu-se o abatimento da parte central com formação de fendas radiais e circulares, que permitiram a subida do magma. A existência, mesmo no atual estágio de erosão, de pequenas áreas de material vulcânico perturbado pela intrusão, indica que o abatimento não foi total, tendo parte do teto servido de encaixante para a formação dos tinguaitos e diferenciação de foiaítos. $\mathrm{Na}$ periferia formou-se o grande dique anelar de tinguaito, com mergulhos verticais ou quase verticais, de espessura variável, formando um anel quase completo. A dedução da forma geométrica da intrusão de tinguaítos da parte central do maciço é dificultada pela grande homogeneidade mineral e textural das rochas. O abatimento iniciou-se no centro, onde a intensidade dêste fenômeno deu-se em maior escala, sendo anterior à formação do dique anelar Evidenciando êste fato, observamos no interior do dique numerosos xenólitos de rochas do interior do maciço. Finalizando os eventos magmá- 
ticos na região deu-se a intrusão dos foiaítos sob a forma de diques menores cortando o grande dique anelar

A seqüência das intrusões parece ser do centro para a periferia, contrariando a observada na maioria das intrusões alcalinas.

O planalto é formado de duas áreas geomorfològicamente distintas: a maior, com drenagem anelar e a menor, com relêvo entre juventude e maturidade, na qual predomina a drenagem radial. E' provável que parte do sistema de drenagem obedeça às direções principais de diaclases.

Após a atividade do magma alcalino ocorreram falhamentos em grande área, dos quais o principal formou o "graben" F-W que tangencia o bordo sul do complexo.

Os recursos minerais são representados por jazidas de bauxita e de minerais zirconíferos como zircão, caldasita, baddeleyta, nos quais há teores variáveis de urânio e os depósitos de tório e terras raras. Os minerais zirconíferos e os de tório são formados a partir de fenômenos ligados a processos hidrotermais, que destruiram os minerais primários e possikjlitaram a posterior precipitação em fendas

\section{BIBLIOGRAFLA}

ANDERSON, E. M. - (1936): The dynamics of the formation of cone sheet, ring-dikes and cauldron subsidences, Proc. Roy. Soc. Edinburg, v. 56, pp. 128-157.

BACKLUND, H. G. - (1933): On the mode of intrusion of deepseated alkaline bodies, Bull. Geol. Inst. Upsala, v. 24, pp. $1-24$.

I;ARBOSA, O. - (1934): Nota sôbre algumas rochas da região de Pocns de Caldas - Acad. Bras. Ciên., Ano 6, pp. 211-219. Rio te Janeiro.

- (1936): Notas preliminares sôbre o planalto de Poços de Caldas e suas possibilidades econômicas, Dep. Nac. Prod. Min., Serv. Fom. Prod. Min., Avulso 8, 33 pp. Rio de Janeiro.

__ (1948): Sôbre a idade das rochas alcalinas e a origem do planalto de Poços de Caldas - Min. Met., v. 13, n. 76, pp. 235237. Rio de Janeiro. 
EILLINGS, M. P - (1943): Ring-dikes and their origin, Trans. N. York. Acad. Sc., ser. 2, v. 5, pp. 131-144.

- (1945): Mechanics of Igneous intrusion in New Hampshire, Amer. Jour. Sc., v. 243-A, Daly Volume, pp. 40-68.

BJöRNBERG, J. A. S. - (1956): Arenitos do bordo do planalto de Poços de Caldas, Anais Acad. Bras. Ciên., v. 28, n. 4, pp. 465-471. Rio de Janeiro.

- (1959): Rochas clásticas do planalto de Poços de Caldas, no prelo

BRANCO, J. J. R. - (1956): Notas sôbre a geologia e petrografia do planalto de Poços de Caldas, M. G., Escola de Engenharia, Univ. Minas Gerais, Inst. Pesq. Radioativas, Publ. n. 5, 72 pp. Belo Horizonte.

CHAPMAN, R. W. - (1935): Percy Ring-dike complex, Amer. Jour. Sc., v. 30, n. 230, pp. 401-431.

CHAPMAN, R. W. e CHAPMAN, C. A. - (1940): Cauldron subsidence at Ascutney Mountain, Vermont, Bull. Geol. Soc. Amer., v. 51, n. 2 , pp. 191-212

Clough, C. T., MAufe, H. B. e BAYley, E. B. - (1909): The cauldron-subsidence of Glen Coe, and the associated igneous phenomena, Quart. Jour. Geol. Soc. London, v. 65, pp. 611-678.

COUtinho, J. M. V - (1959): Petrologia do Maciço de Poços de Caldas (em elaboração)

DERBY, O. A. - (1887): On nepheline rocks in Brasil, with special reference to the association of phonolite and foyaite, Quart. Jour. Geol. Soc., v. 43, pp. 457-473.

ELLisEEV, N. A., OGINSKY, J. S. e VOLODin, E. N. - (1937): Geological and Petrographical description of the Khibine Tundras, Int. Geol. Congress, XVI Session, pp. 51-85.

FRANCO, R. R. -- (1947): Minerais de zircônio na região de Poços de Caldas, Minas Gerais, Bol. Fac. Fil., Ciên. Letr., Univ. S. Paulo, n. 99, Mineralogia n. 7, pp. 7-28. São Paulo.

FREITAS, R. O. de - (1943): As estruturas fósseis do sistema Santa Catarina no planalto de Poços de Caldas, Ass. Geogr. Brasil. Ano 3, n. 3, pp. 25-37 São Paulo.

- (1947): Geologia e Petrologia da Ilha de São Sebastião, Bol. Fac. Fil., Ciên. I.etr., Univ. São Paulo, n. 85, Gẹologia n. 3, 244 pp. São Paulo.

_ (1951): Ensaio sôbre a tectônica moderna do Brasil, Bol. Fac. Fil., Ciên. Letr., Univ. São Paulo, n. 130, Geologia n. 6, 120 pp. São Paulo. 
- (1953): Ensaio sôbre o relêvo tectônico do Brasil, Rev. Bras. Geog., Ano 13, n. 2, pp. 171-222. Rio de Janeiro.

__ (1956): Sôbre um akerito da Serra do Mirante, Bol. Soc. Bras. Geol., v. 5, n. 2, pp. 77-90. São Paulo.

GUIMARÃES, D. - (1947): Origem das rochas alcalinas, Inst. Tec. Ind. Minas Gerais, Bol. n. 5, 103 pp. Belo Horizonte.

- (1948): The zirconium ore deposits of the Poços de Caldas Pleteau, Brazil, and zireonium geochemistry, Inst. Tec. Ind., n. 6,79 pp. Belo Horizonte.

GUIMARÃES. D., CAMPOS, M. e FIGUEIREDO, D. G., (1953): Algumas rochas alcalinas de Focos de Caldas relacionadas com as jazidas de caldasito uranífero, Escola de Engenharia da Univ. de Minas Gerais, Instituto de Pesquisas Radioativas, public. n. 2, pp. 1-34. Belo Horizonte.

HUSSAK, E. - (1900): Uber ein leukokrates gemischtes Ganggestein der Serra de Caldas, Brasilien, N. Jb. f. Min. Geol. u. Paìeo., B. I, pp. 22-27

JOHANNSEN, A. - (1939): A descriptive Petrography of the Igneous Rocks, v. 1-4, The University of Chicago Press, Chicago, Illinois.

KINGSLEY, L. - (1931): Cauldron-subsidence of the Ossipee Mountains, Amer. Jour. Sc., 5th Ser., v. 22, n. 222. pp. 139-168.

KORN, H. e MARTIN, H. - (1953): Der Intrusionsmechanismus der grossen Karroo-Plutone in Südwestafrika, Geol. Rundschau, v. 41, Sonderband, pp. 41-58.

(1954): The Messum Igneous complex in South West Africa, Trans. Proceed. Geol. Soc. South Africa, v. 57, pp. 83-124.

LAMEGO, A. R. - (1936): 0 maciço do Itatiaia e regiōes circundantes, Dep. Nac. Froc. Min., Serv Geol. Min., Bol. n. 88, 93 pp. Rio de Janeiro.

I.EINZ, V - (1940): Petrologia das jazidas de apatita de Ipanema (Est. São Paulo), Dep. Nac. Prod. Min., Div. Fom. Prod. Min., Bol. n. 40, 52 pp. Rio de Janeiro.

— (1949): Contribuição à geologia dos derrames basálticos do Sul do Brasil, Bol. Fac. Fil., Ciên. Letr., Univ São Paulo, Geologia n. 5, 61 pp. São Paulo.

LlNDGREN, W - (1933): Mineral Deposits, McGraw-Hill Book Company, Ind., 930 pp. N. York.

MACHADO, J. - (1888): Beitrag zur Pełrographie der südwestlichen Grenze zwischell Minas Gerais und São Paulo, Tscher. Min. u. Petr. Mitt., Bd. 9, pp. 329-360. 
MIODELL, D. - (1936): Ring-Dike complex of Belknap Mountains, N. Hampshire, Bull. Geol. Soc. Amer., v. 47, n. 12, pp. 1885-1932

OLIVEIRA, A. I. de - (1956): Ocorrências brasileiras de Urânio, Min. Met., v. 24, n. 142, pp. 209-212. Rio de Jareiro.

RAMSAY, W - (1894): Das Nephelin Gebiet auf der Halbinsel Kola I, Fennia II.

RICHEY, J. E. e THOMAS, H. H. - (1932): The ring complex of Slieve Guillion, Quart. Jour. Geol. Soc. London, v. 88, pp. 776-846.

SHAND, S. J. - (1929): The geology of Pilansberg in the Western Transvaal: A study of alkaline rocks and ring-intrusions, Trans. Geol. Soc. South Africa, v. 31, pp. 97-156.

STRAuss, C. A. e TRUTER, F. C. - (1954): The Alkali Complex at Spitzkop, Sekukuniland, Eastern Transvaa!, Trans. Geol. Soc. South Africa, v. 53, pp. 81-130.

TEIXEIRA, E. A. - (1937): Zircônio no planalto de Poços de Caldas, Est. de S. Paulo e Minas Gerais, Min. Met., v. 1, n. 4, pp. 159-168. Rio de Janeiro.

- (1937): Bauxica no planalto de Puços de Caldas, Estado de Minas Gerais, Min. Met., v 1, n. 5, pp. 205-214. Rio de Janeiro.

TOLBERT, G. - (1958): Preliminary report of the zirconium ore deposits of the Poos de Caldas Plateau, Eng. Mir. Met., v. 27, n. 161, Part I, n. 162, Part II.

USSING, N. V. - (1911): Geology of the Country around Julianehaab, Greenland, Med. Grönl., v. 38.

von ECKERMANN, H. - (1948): The Alkaline District of Alnö Island, Sveriges Geologiska Undersokning, Ser. Ca. n. 36 , $176 \mathrm{pp}$. 


\section{I $\mathrm{N} \mathrm{D} \mathrm{I} \mathrm{C} \mathrm{E}$}

\begin{tabular}{|c|c|c|c|c|c|c|c|c|c|c|}
\hline Abstract & . & & . & . & & & . & . & & 5 \\
\hline Introdução & . & . & . & $\ldots$ & & & . & & & \\
\hline Trabalhos anteriores & & & & . . & . & . & & . & & 10 \\
\hline Geologia Regional & . & & . & $\cdots$ & & & & . & & 11 \\
\hline Geologia do Maciço & Alcalino & & . & . & & & . & $\cdots$ & & 12 \\
\hline Mecanismo da Intru & são Alcalina & & . & & & & & & & 28 \\
\hline Comparação com ou & tros Jazimen & tos c & de & Roch & las & Alc & calin & las & & 44 \\
\hline Tectônica $\quad \ldots \quad \ldots$ & .. & $\cdots$ & . & & $\ldots$ & & & & & 45 \\
\hline Mapa Geológico .. & & & & & . & & . & . & & 50 \\
\hline Recursos Minerais & $\ldots \ldots$ & & & . & . & & . & & . & 57 \\
\hline Resumo & $\ldots \ldots$ & $\cdots$ & & $\ldots \ldots$ & ... & & ... & $\cdots$ & . & 58 \\
\hline Bibliografia $\quad \ldots \quad \ldots$ & & & & & & & & & & \\
\hline
\end{tabular}

